\title{
A plague of waterfleas (Bythotrephes): impacts on microcrustacean community structure, seasonal biomass, and secondary production in a large inland-lake complex
}

\author{
W. Charles Kerfoot - Martin M. Hobmeier - Foad Yousef • \\ Brenda Moraska Lafrancois • Ryan P. Maki · Jodi K. Hirsch
}

Received: 5 July 2015/Accepted: 31 December 2015/Published online: 29 February 2016

(C) The Author(s) 2016. This article is published with open access at Springerlink.com

\begin{abstract}
The spiny cladoceran (Bythotrephes longimanus) is an invasive, predaceous zooplankter that is expanding from Great Lakes coastal waters into inland lakes within a northern latitudinal band. In a large, Boundary Water lake complex (largely within Voyageurs National Park), we use two comparisons, a 2-year spatial and a 12-year temporal, to quantify seasonal impacts on food webs and biomass, plus a preliminary calculation of secondary production decline. Bythotrephes alters the seasonal biomass pattern by severely depressing microcrustaceans during summer and early fall, when the predator is most abundant. Cladoceran and cyclopoid copepods suffer the most serious population declines, although the resistant cladoceran Holopedium is favored in spatial
\end{abstract}

W. C. Kerfoot $(\bowtie) \cdot$ M. M. Hobmeier · F. Yousef Great Lakes Research Center and Department of Biological Sciences, Michigan Technological University, Houghton, MI 49931, USA

e-mail: wkerfoot@mtu.edu

B. M. Lafrancois

National Park Service, 2800 Lake Shore Drive East, Ashland, WI 54806, USA

R. P. Maki

Voyageurs National Park, 415 S Pokegama Avenue, Grand Rapids, MN 55744, USA

\section{J. K. Hirsch}

Minnesota Department of Natural Resources (MN DNR), 500 Lafayette Road, Box 25, St. Paul, MN 55155-4025, USA comparisons. Microcrustacean biomass is reduced 40-60 \% and secondary production declines by about $67 \%$. The microcrustacean community shifts towards calanoid copepods. The decline in secondary production is due both to summer biomass loss and to the longer generation times of calanoid copepods (slower turnover). The Bythotrephes "top-down" perturbation appears to hold across small, intermediate, and largesized lakes (i.e. appears scale-independent), and is pronounced when Bythotrephes densities reach 20-40 individuals $\mathrm{L}^{-1}$. Induction tests with small cladocerans (Bosmina) suggest that certain native prey populations do not sense the exotic predator and are "blindsided". Failure of prey to deploy defenses could explain the disproportionate community impacts in New World versus Old World lakes.

Keywords Spiny cladoceran · Food web impacts · Seasonal biomass - Microcrustacean communities . Secondary production

\section{Introduction}

There is growing awareness that freshwater communities are more seriously threatened by the introduction of non-indigenous species than by atmospheric pollution, agricultural land use practices, or even global climate change (Vitousek et al. 1996; Simberloff and Van Holle 1999; Sala et al. 2000). In the 
Great Lakes region, exotic species impacts are major and accumulative (Mills et al. 1993; Ricciardi 2006). The spiny cladoceran (Bythotrephes longimanus) is an invasive, predaceous zooplankter that impacts Great Lakes assemblages and that is spreading out from coastal waters to colonize inland lakes across a temperature-related northern latitudinal band (Fig. 1; Kerfoot et al. 2011). The inland region stretches from Vermont, eastern Ontario, and New York, through Michigan, Wisconsin, Minnesota and Manitoba.

In the first stage of New World expansion, the spiny cladoceran invaded very large lakes, e.g. all of the Laurentian Great Lakes by 1987 (Fig. 1; Lehman 1987; Cullis and Johnson 1988). Initial study of Bythotrephes in the Great Lakes yielded some insights into the species' colonization characteristics. For a cladoceran, Bythotrephes carries a long, barbed caudal appendage (Fig. 1, insert). The tail spine protects Bythotrephes from small young-of-the year (YOY) fish (Barnhisel 1991a, b), although larger fish can ingest great numbers of adults (Mills et al. 1992; Branstrator and Lehman 1996). Bythotrephes is epilimnetic and metalimnetic, and sometimes hypolimnetic in reservoirs during the day. There are often midsummer density oscillations (Berg and Garton 1988; Lehman 1991), and individuals have high energetic demands (Lehman and Cáceres 1993; Yurista et al. 2010). In the Great Lakes, Bythotrephes were observed to depress herbivorous cladocerans such as D. retrocurva and Bosmina (Lehman and Cáceres

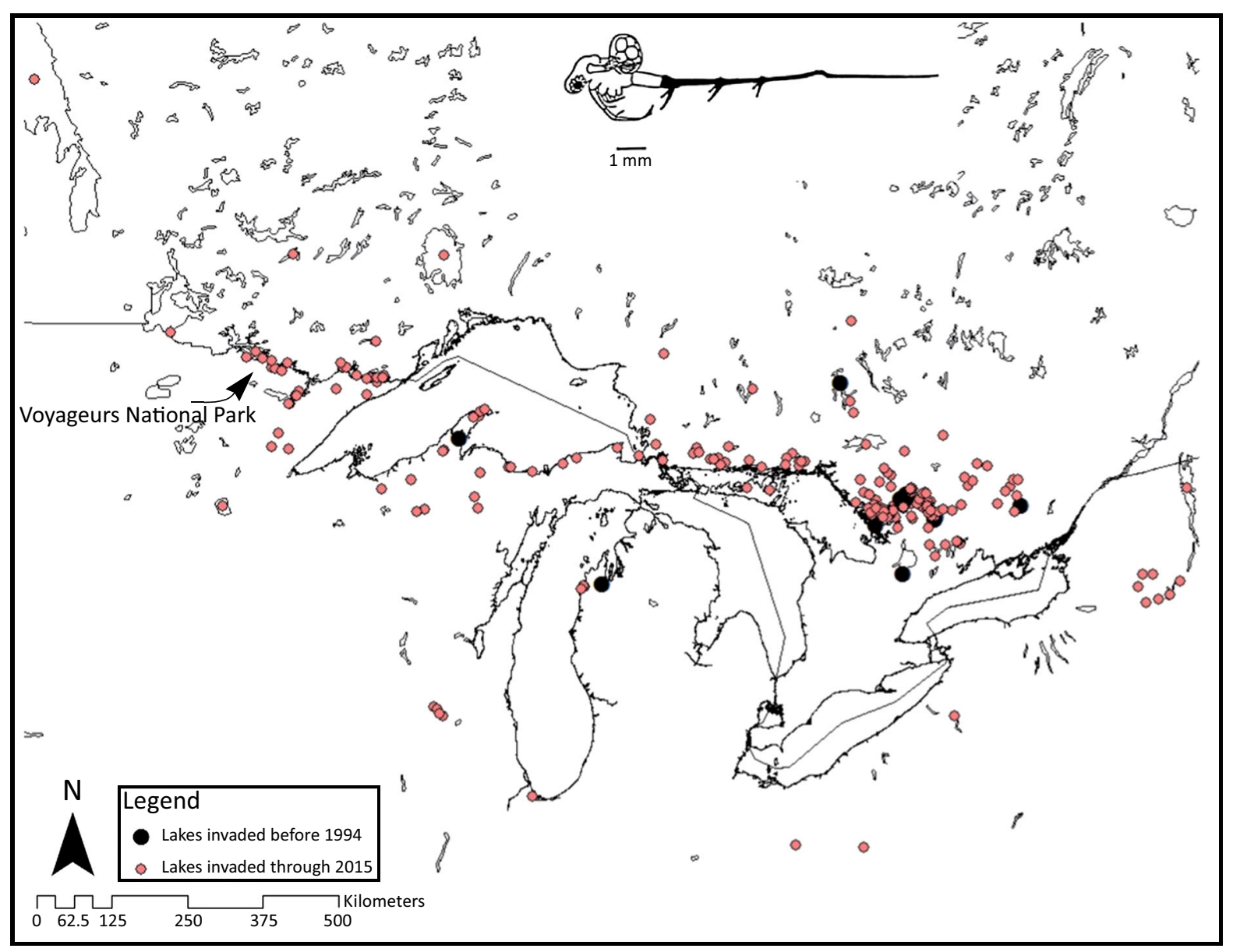

Fig. 1 Geographic distribution of the spiny cladoceran Bythotrephes longimanus (inset). The spiny cladoceran is present in all the Great Lakes, but early inland lake colonization patterns seemed scattered (1994; large black dots). Recently, there is a clear spread eastward and westward in a latitudinal band (2015; small pink dots). Voyageurs Park site is located along the Boundary waters of Northern Minnesota 
1993; Barbiero and Tuchman 2004). Despite the spine's effectiveness against YOY fish (Jarnagin et al. 2004; Compton and Kerfoot 2004), spiny cladocerans survived under a delicate demographic balance. Although generation times were short, enough larger fish consumed the cladoceran that ingestion by fish contributed an estimated 40-70\% of annual mortality (Jarnagin et al. 2004; Pothoven et al. 2007).

In the second stage of geographic expansion, after colonizing embayments and harbors, Bythotrephes began to invade relatively small inland lakes (Fig. 1; MacIsaac et al. 2000, 2004; Yan et al. 2001; Branstrator et al. 2006; Kerfoot et al. 2011). Rapid inland expansion across the northern US states and Canadian provinces is linked to recreational fishing. Dispersal was promoted by snagging of tail spines on fishing lines, anchor ropes, nets and minnow seines, but also by use of local baitfish and inter-lake transfer of fish. The unusual thick-shelled diapausing eggs can pass through fish guts in viable condition (Jarnagin et al. 2000, 2004). Inspection of fish guts (yellow perch, cisco, alewives) documented that large numbers of viable eggs end up in stomachs during summer and fall (Jarnagin et al. 2004; Kerfoot et al. 2011). Diapausing eggs that pass through fish guts may be defecated into live wells and bait buckets, or the eggladen fish transferred from one lake to another.

Much of the recent demographic and food-web impact information has come from studies of relatively small lakes: Harp Lake, Ontario (Yan and Pawson 1997; Yan et al. 2001), Lake Michigamme, Michigan (Jarnagin et al. 2000, 2004), and an additional series of eastern Ontario lakes (Strecker and Arnott 2005; Strecker et al. 2011). During the daytime, egg-carrying adult Bythotrephes seek shelter in epilimnetic strata between the bottom of the photic zone and the top of the hypolimnion, reducing risk from fish consumption. In small lakes, Bythotrephes became most abundant in summer (July, August). In Harp Lake, Bythotrephes caused shifts in zooplankton size and species composition, reducing small cladoceran density and overall species richness, while favoring the gelatin capsule-protected cladoceran Holopedium (Yan et al. 2002). In Harp Lake, prey species selections were similar to those observed in Swedish mesocosm investigations, within the predator's natural habitat (Wahlstrom and Westman 1999). However in Europe, Bythotrephes generally does not have the serious biomass and biodiversity effects observed in North America and often co-occurs with taxa that we see removed from northern Midwestern lakes (Straile and Haelbich 2000; Korovchinsky 2000; Kelly et al. 2013).

Thus previous geographic knowledge comes from a mixture of very large and relatively small lakes. Here we use extensive spatial and temporal sampling in Voyageurs National Park lakes to examine responses in an inter-connected, intermediate-sized series of lakes, to see if prior observations are scale-independent. Our study benefits from extensive and historical sampling before, during, and after colonization. Moreover, the interconnected lakes resemble, in miniature, circumstances in the Great Lakes. Initial documentation sets the stage for even longer-term observations. For example, because there are substantial community biomass effects, we could examine "cascading effects" up and down food webs. Moreover, one might expect resting-egg "seed banks" to initially moderate effects. Despite strong depressions of vulnerable species, populations may linger until recruitment from "egg banks" is depleted.

We report that, as in smaller lake studies, Bythotrephes is creating major, progressive impacts on microcrustacean assemblages. Even though the lakes are larger in size than previous inland studies, there are severe shifts in microcrustacean seasonal density patterns, community composition, biomass and secondary productivity. In addition, there are initial indications of "cascading effects" in colonized waters. We also observe that species appear to be barely hanging on, at very low densities, an indication of initial "seed bank" moderation of losses. Because there are fewer multiple stressors (no zebra or quagga mussel colonization, fewer changes in fish stocking, lack of phosphorus abatement) in Voyageurs National Park waters, the studies may aid interpretation of recently observed shifts in Laurentian Great Lakes food webs due to increased Bythotrephes density. We also begin to address the question of disproportionate food-web effects between New World and Old World food webs by including Bythotrephes in prey "induction" experiments. Small cladocerans (Bosmina, Eubosmina, Ceriodaphnia) typically respond to natural predators by deploying a variety of defensives. However, Bosmina fail to react to Bythotrephes, as if prey individuals are incapable of sensing the presence of the exotic predator and are "blind-sided" by its 
presence. Disproportionate effects of invasive predators are often thought to derive from prey lacking the ability to detect or respond appropriately to novel predators, due to absence of shared evolutionary history [i.e. prey naiveté hypothesis, Cox and Lima (2006)]. Several studies report a lack of recognition of invasive predators by native prey that lack an evolutionary history with the predator (Shave et al. 1994; Smith et al. 2008).

\section{Methods}

Northern geographic expansion

The species is well spread across Ontario, occupying a band with a cluster in central Ontario (Fig. 1). South of the international boundary, the colonization stretches into New York and Vermont. Towards the west, the species has moved through Michigan, Wisconsin, and into Minnesota. Expansion of Bythotrephes into the 10,000 lake district of northern Minnesota and western Ontario along a preferred temperature band (Kerfoot et al. 2011) places the entire northern region at great risk. Bythotrephes appears to prefer $14-23{ }^{\circ} \mathrm{C}$ waters (Yurista 1999). Prolonged temperatures above $25-26{ }^{\circ} \mathrm{C}$ can cause reproductive failure (Garton et al. 1990; Yurista 1999), which explains the lack of Bythotrephes colonization in southern Wisconsin, Minnesota, and Michigan inland lakes (Kerfoot et al.
2011). The temperature regimes found in Voyageur's lakes (Table 1), and regional boundary waters, seem ideal for colonization. The large Voyageurs lake complex also provides an example that falls between small inland and exceptionally large lakes (e.g. Laurentian Great Lakes).

Food-web effects: background and procedures

Voyageurs National Park is located in northern Minnesota (Fig. 2). The Park was established in 1975 around a system of four interconnected lakes (Kabetogama, Namakan, Rainy, Sand Point), plus associations with Crane and Little Vermilion Lakes on the southeastern edge, all occupied by zooplankton that seem a mixture of glacial relic, mesotrophic lake, and a few eutrophic bay species. The large interconnected lakes include Rainy Lake $\left(932 \mathrm{~km}^{2}\right.$ surface area), Namakan Lake $\left(97.4 \mathrm{~km}^{2}\right.$ ), Kabetogama Lake $\left(97.3 \mathrm{~km}^{2}\right)$, and Sand Point Lake $\left(34.5 \mathrm{~km}^{2}\right)$. Crane Lake $\left(11.8 \mathrm{~km}^{2}\right)$ and Little Vermilion Lake $\left(5.2 \mathrm{~km}^{2}\right)$ are linked to Sand Point Lake along a southeastern corridor and lie just outside of park boundaries. Four of the lakes straddle the International Boundary between Canada and the United States (heavy black line). Portions of the large lakes and more than 30 named smaller interior lakes (ranging in size from 0.08 to $3.05 \mathrm{~km}^{2}$ ) comprise more than half of the park's total area of $883 \mathrm{~km}^{2}$.

Table 1 Physical and chemical features of six boundry lakes in or near Voyageurs National Park

\begin{tabular}{|c|c|c|c|c|c|c|}
\hline Variable & Rainy & Namakan & Kabetogama & Sand Point & Crane & Little Vermilion \\
\hline Surface area $\left(\mathrm{km}^{2}\right)$ & 932 & 97.4 & 97.3 & 34.5 & 11.8 & 5.2 \\
\hline Maximum depth (m) & 49.1 & 45.7 & 24.4 & 56.1 & 24.4 & 15.9 \\
\hline August Temperature $\left({ }^{\circ} \mathrm{C}\right)$ & 20.8 & 21.8 & 22.3 & 20.9 & 22.6 & NA \\
\hline Secchi depth (m) & 2.8 & 3.3 & 2.7 & 2.4 & 2.7 & 2.3 \\
\hline Chlorophyll $a(\mu \mathrm{g} / \mathrm{L})$ & $2-10$ & $2-5$ & $5-30$ & $2-5$ & 3 & 4 \\
\hline Alkalinity (mg/L) & $15-16$ & 15 & $38-39$ & 18 & NA & NA \\
\hline $\mathrm{Ph}$ & 7.5 & 7.1 & 7.9 & 7.4 & NA & NA \\
\hline Hardness $\left(\mathrm{mg} / \mathrm{L}\right.$ of $\left.\mathrm{CaCO}_{3}\right)$ & 16.1 & 14 & 39.9 & 16.4 & NA & NA \\
\hline Total P $(\mu \mathrm{g} / \mathrm{L})$ & $15-20$ & $9-15$ & $20-50$ & 15 & 17 & 17 \\
\hline Total N $(\mu \mathrm{g} / \mathrm{L})$ & 450 & 500 & 750 & 550 & NA & NA \\
\hline Trophic State Index (TSI) & 46 & 39 & 49 & 44 & 46 & 46 \\
\hline
\end{tabular}

The lakes are interconnected and have highly irregular shorelines. Water quality values are taken largely from Hargis et al. (1981) and Kallemeyn et al. (2003). August temperatures are from our 2008-2010 temperature probe studies 
Fig. 2 Sampling stations (black dots) in Voyageurs Park lakes (Rainy,

Kabetogama, Namakan, Sand Point) and in the southeastern Crane and Little Vermilion Lakes. The thick black line traces the International Boundary between the US and Canada through the lakes, whereas the thinner black line marks the southern park boundary

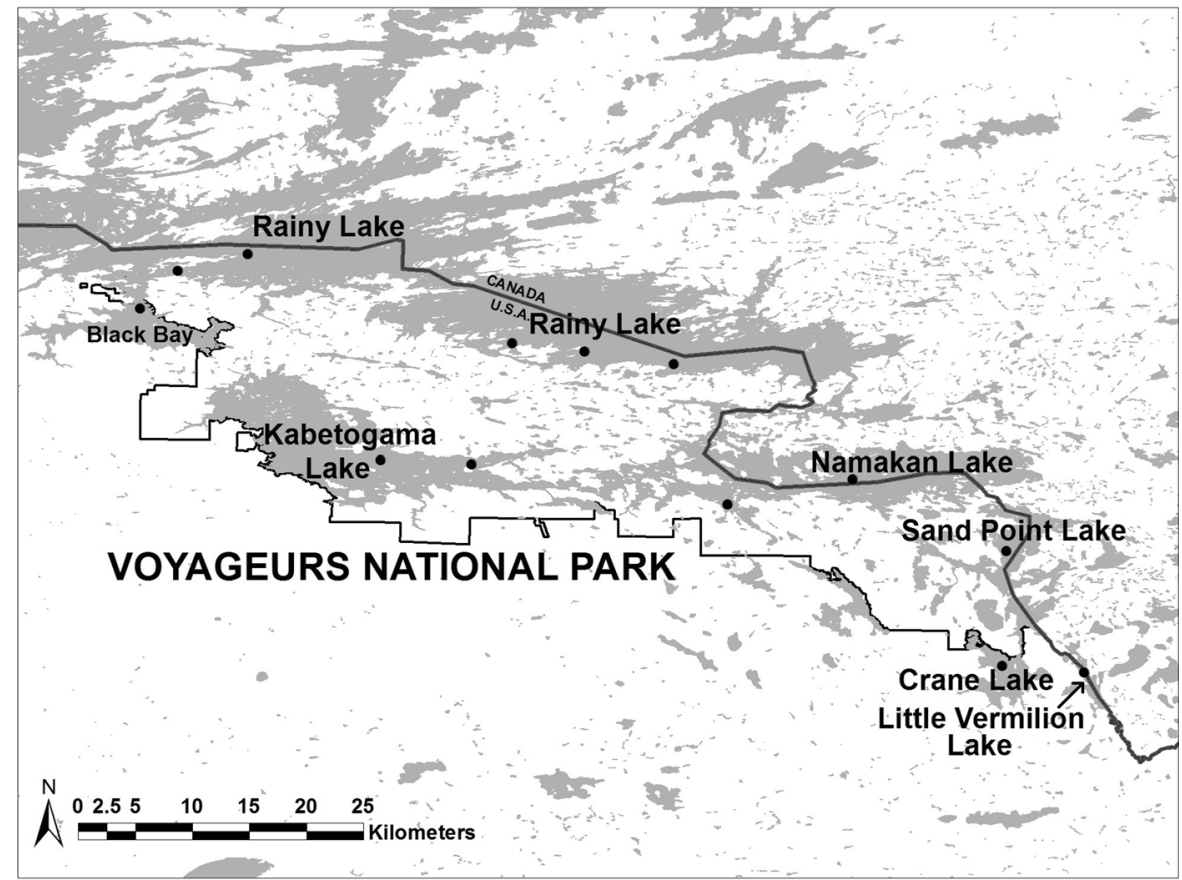

The lakes share several general limnological features (Table 1). All five interconnected lakes are ice-covered 5 months out of the year, and four maintain thermal stratification during the warm season. The exception is Kabetogama, which is polymictic. Mean August temperatures range between 20.8 and $22.3{ }^{\circ} \mathrm{C}$. All are soft-water lakes $\left(\mathrm{CaCO}_{3}\right.$ concentrations $\left.=12.2-44.8 \mathrm{mg} / \mathrm{L}\right)$, with a wide range in productivity. Rainy, Namakan, and Sand Point have been oligotrophic since 2000, whereas Kabetogama is mesotrophic, with shallowwater regions $<15 \mathrm{~m}$ deep) bordering on eutrophic. The relatively large Black Bay region $\left(22.6 \mathrm{~km}^{2}\right.$; $3 \mathrm{~m}$ depth) of Rainy Lake is also much more productive, bordering on eutrophic conditions. Bythotrephes was established in Rainy, Kabetogama and Namakan Lake by 2007. The species has since been reported in Sand Point, Crane, and Little Vermilion lakes, although population densities in the latter three lakes were still quite low in 2009 (Fig. 3).

Prior to our studies, several surveys of Voyageurs National Park established physical, chemical, and biological properties (Table 1). Dates for four microcrustacean surveys include an early University of Minnesota survey (1973, 1976), Hargis' samples (1978-1980), extensive investigations by the Park

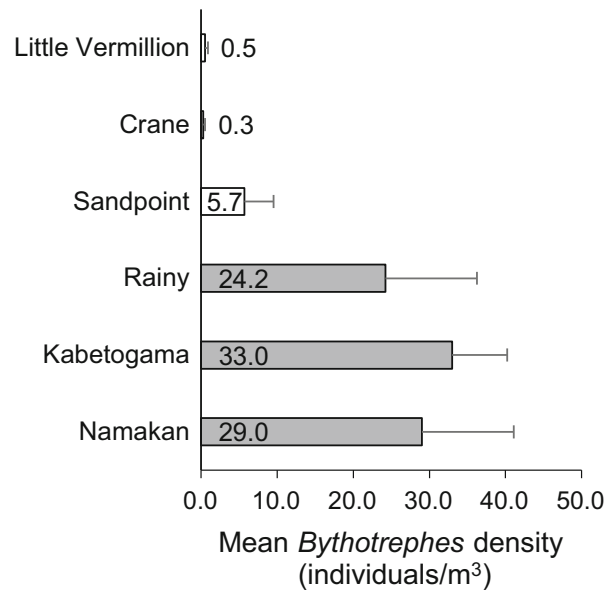

Fig. 3 Mean ( \pm 1 SE) Bythotrephes densities in lakes in or near Voyageurs National Park, 2009-2010. In the Spatial Contrast dichotomy, the grey-shaded lakes cointain "high" densities of Bythotrephes (i.e., Namakan, Kabetogama, Rainy), whereas lakes with clear bars have relatively "low" densities (i.e., Sand Point, Crane, Little Vermilion)

and USGS personnel during 1981-1984, plus repeated USGS sampling of Namakan and Rainy Lakes during 1996. Previous survey results were published in Hargis et al. (1981) and a USGS report (USGS/BRD/ITR 2003). The early surveys found a diverse cladoceran 
assemblage, including Daphnia longiremis, D. pulicaria, D. galeata mendotae [sic], D. retrocurva, socalled Bosmina longirostris, Eubosmina coregoni, Chydorus sphaericus, Diaphanosoma leuchtenbergianum (now D. birgei), Ceriodaphnia lacustris, $C$. quadrangula, and Holopedium gibberum. The large, predatory cladoceran, Leptodora kindtii, was also frequently detected. The most commonly occurring cyclopoid copepods were Diacyclops bicuspidatus thomasi, Tropocyclops prasinus, Acanthocyclops vernalis, and Mesocyclops edax. The most abundant filter-feeding calanoid copepods were Diaptomus ashlandi, D. sicilis, Skistodiaptomus oregonensis, and Leptodiaptomus minutus. Large omnivorous calanoid copepods included Epischura lacustris, Limnocalanus macrurus, and Senecella calanoides. Plankton samples in deeper lakes also included occasional opossum shrimp (Mysis diluviana) and a variety of phantom midges (Chaoborus spp.), all of which exhibited vertical migration.

All of the large interconnected lakes had similar zooplankton communities prior to Bythotrephes arrival (Hargis et al. 1981; Kallemeyn et al. 2003). At Voyageurs, we used two independent sampling comparisons to examine food web impacts after Bythotrephes colonization. The first we termed a Spatial Contrast approach. During 2009-2010, microcrustacean communities from Voyageurs' lakes that contained high densities of Bythotrephes (3 lakes) were compared with lakes that contained low densities ( 3 lakes). The second comparison was termed a Temporal Contrast. Here we compared pre- versus post-invasion zooplankton communities in the three high Bythotrephes-density lakes (Rainy, Namakan, and Kabetogama), using long-term periodic sampling done independently from the spatial contrast sampling.

\section{Spatial contrast}

The Spatial Contrast approach determined mean Bythotrephes densities in each lake during 2009-2010 (Fig. 3). We classified three lakes (Rainy, Kabetogama and Namakan) as "high-density" (shaded bars; 24.2, 33.0, and 29.0 Bythotrephes $\mathrm{m}^{-3}$, respectively), whereas Sand Point, Crane, and Little Vermilion were designated "low-density" lakes (clear bars; 5.7, 0.3, 0.5 Bythotrephes $\mathrm{m}^{-3}$ ). Monthly zooplankton samples were collected from 13 stations (Fig. 2) during the summers of 2009 and 2010, with sampling sites dispersed more or less equidistant across the space of the interconnected system. Sampling sites in the larger lakes were close to sites used for routine, long-term bi-weekly vertical tows associated with water quality monitoring (see Temporal Contrast). Six stations were in Rainy Lake (including one in the shallow, more eutrophic Black Bay), two stations each in Namakan and Kabetogama, and one station each in Sand Point, Crane, and Little Vermilion Lakes. At each station, two tows were taken vertically from bottom to surface with a single $25 \mathrm{~cm}$-diameter Wildco Plankton Net (125 $\mu \mathrm{m}$ Nitex mesh), whereas one long tow was collected diagonally (horizontal) in the epilimnion with a $50 \mathrm{~cm}$-diameter, $350 \mu \mathrm{m}$ mesh Nitex net (Research Nets, Inc., Bothell, Washington). The $350 \mu \mathrm{m}$ net was equipped with a unidirectional flow meter for calculating sampled water volume, and was drawn from the thermocline to the surface. The flow meter was checked dockside at MTU and the towed track length in the field with a Magellen Triton GPS meter. Samples were rinsed into $500 \mathrm{~mL}$ Nalgene plastic sample jars, preserved in $10 \%$ formalin/sucrose, and kept in cold storage until processed. Results from the two vertical tows were averaged. However, horizontal large-net tows greatly improved density estimates for large-bodied epilimnetic predators and prey (e.g. Bythotrephes, Leptodora, Holopedium, Daphnia mendotae, Epischura) relative to numbers captured in smaller vertical net tows, and these values were used for the larger-bodied taxa. In particular, Holopedium showed a tendency for high spatial clumping, and was best sampled with the larger, horizontal coarse mesh tows. The Spatial Contrast net tows were done during June, July, August and September, producing 67 site density estimates over the 2-year (2009-2010) interval.

In the laboratory, collections were stirred in a beaker with a magnetic stirring rod, then a subsample constituting at least $10 \%$ of the sample by volume was taken with a Hensen-Stempel Pipette. All microcrustaceans belonging to cladoceran and copepod taxa were identified following Balcer et al. (1984) and Haney et al. (2013). Counting was done under an Olympus dissecting microscope at $40 \times$, whereas lengths for biomass calculations were measured at 80X, using a 2X WD38 auxiliary lens. For larger predatory species (e.g. Bythotrephes, Leptodora, Limnocalanus), every individual in the sample was counted. For copepods, nauplii were counted 
separately and lumped into one category. Pelagic densities for microcrustacean taxa were based on counts, whereas length measurements were used to estimate biomass using published length/weight regression models (e.g., Culver et al. 1985; Manca and Comoli 2000). Densities and biomass of microcrustacean taxa were compared between the two sets of lakes (high Bythotrephes density, low Bythotrephes density) using a one-way Analysis of Variance (ANOVA) on log-transformed data. The Spatial Contrast series captured spatial impacts at a brief moment during a time when the Bythotrephes population was actively expanding spatially in Voyageurs National Park.

Taxa abundant enough to be tallied in the Spatial Contrast series included the cladocerans Daphnia longiremis, D. pulicaria, D. mendotae (formerly $D$. galeata mendotae), D. retrocurva, Bosmina sp., Diaphanosoma birgei, and Holopedium gibberum. Densities for the large, predatory cladoceran, Leptodora kindtii, were also tabulated. Cyclopoid copepods included Diacyclops bicuspidatus thomasi, Acanthocyclops vernalis, Tropocyclops prasinus and Mesocyclops edax. Filter-feeding diaptomid calanoid copepods were lumped together into one herbivorous category, Diaptomidae, separate from the omnivorous large-bodied taxa, Epischura lacustris and Limnocalanus macrurus. Dominant species of filter-feeding diaptomid copepods included Leptodiaptomus sicilis, Leptodiaptomus ashlandi, and Skistodiaptomus oregoninsis in the collective category.

\section{Temporal contrast}

In the Temporal Contrast approach, we utilized a longterm data set collected in the large lakes (Rainy, Namakan, Kabetogama) by the National Park Service in collaboration with the Minnesota Department of Natural Resources (Minnesota DNR) and the United States Geological Survey (USGS). In the DNR yearly sampling, microcrustacean plankton assemblages were sampled at twelve sites within Voyageurs (Fig. 2; i.e., all four large lakes; unfortunately there was no pre-Bythotrephes sampling in Crane and Little Vermilion Lakes) using vertical tows with a $30 \mathrm{~cm}$ diameter Wildco Hensen Egg Net $(153 \mu \mathrm{m}$ Nitex mesh). At each station, two separate vertical hauls were taken. Each year, samples were collected monthly from May to October. To compare pre- with post-colonization communities, pre-invasion zooplankton data from 2001 to 2003 were compared with more recent, post-invasion data from 2007 to 2010 in the high-density Bythotrephes lakes (Rainy, Namakan, Kabetogama) during summer months (June, July, and August). We stress that the Temporal Contrast samples were an independent set of collections than those used in the Spatial Contrast, although site proximity (almost the same locations) and some time overlap (2009-2010) are likely to foster close correlations. The temporal sequence was intended to compare differences before and after Bythotrephes arrival in the three largest lakes during months when Bythotrephes were present. In contrast, the Spatial Contrast had Bythotrephes in all lakes, although with relative "high" versus "low" densities. The Temporal Contrast comparisons also integrated samples over a much greater period of time, and included full vertical (epilimnetic-hypolimnetic) profile coverage. The temporal series included a total of 237 independent samples for comparisons. We contrasted pre-invasion to post-invasion species biomass using one-way ANOVA (i.e. contrasting before and after predation dichotomy) on log-transformed data. Logarithmic transformation was applied to normalize data. Because biomass calculations utilized density estimates transformed by biomass regressions, relative differences for density and biomass were expected to be very similar. To judge differences in diversity, we calculated the Shannon-Wiener Index (H') of diversity for late-summer assemblages, using species categories and density. As a check, we also ran an independent ANOVA analysis on Sand Point Lake, a lake where there was pre- and post-Bythotrephes sampling, but where spiny cladocerans were in relatively low, but rising, abundance (Fig. 3).

In past park surveys, bosminids were placed into two categories: a small-bodied species, Bosmina longirostris, and a slightly larger species, Eubosmina coregoni. Although modern electrophoretic and genesequencing studies show that the predominantly European species $B$. longirostris does exist in North America, two recently described small-bodied species, B. liederi and B. freyii, are the usual upper Midwestern species in larger lakes (Taylor et al. 2002; Kerfoot and McNaught 2010). The genus Eubosmina can be distinguished from the two smaller Bosmina species by lateral head pore position. Eubosmina occurs as either the larger invasive species E. coregoni, which 
usually lacks a tail spine (mucro), or the naturally occurring slightly smaller species $E$. longispina, which has a well-developed mucro. In our investigations, because several species fell under the two genera, for convenience we lumped individuals into only two categories: Bosmina spp. and Eubosmina spp.

\section{Principal components analysis}

To help density and biomass variables conform to a normal distribution, both were subjected to logarithmic transformation. As mentioned earlier, in the Spatial and Temporal Contrasts, we used a one-way Analysis of Variance (ANOVA) to establish significance levels. However, to further investigate and display collective correlation patterns between species densities, we applied a Principal Component Analysis (PCA) ordination on the biomass correlation matrix to examine cluster patterns. Factor loadings (eigenvalues) for the Principal Components are shown in figures for the first three orthogonal axes (eigenvectors). Analyses utilized SYSTAT 12 (SYSTAT Software, Inc. 2007) on a PC platform. Axes were ranked by their eigenvalues and Scree tests indicated the appropriate number of significant axes. Typically only 3-4 factors (eigenvalues) were significant, so we plotted the first three in a 3-dimensional diagram. The clusters aided species-by-species comparisons, so they were included in the general treatment.

\section{Preliminary secondary production calculations}

Potential changes in "Secondary Production" were estimated using the following model from Shuter and Ing (1997):

$\log _{10}\left(\mathrm{P} / \mathrm{B}_{\mathrm{gs}}\right)=\alpha+\beta\left(\mathrm{T}_{\mathrm{gs}}\right)+\Phi\left(\log _{10}(\mathrm{gs})\right)$

where $\mathrm{P} / \mathrm{B}_{\mathrm{gs}}$ is the ratio of "Secondary Production" to "Biomass" over the growing season for taxon categories. In the equation, $\alpha, \beta$, and $\Phi$ are constants, with $\alpha$ being distinct for each of the three taxon categories (cladocerans, cyclopoid copepods, and calanoid copepods). Values for the constants $(\alpha, \beta, \Phi)$ were taken directly from Shuter and Ing (1997), derived from numerous studies. The variables $\mathrm{T}_{\mathrm{gs}}$ and gs refer to daily temperature $\left({ }^{\circ} \mathrm{C}\right)$ over the growing season, and the total length of the growing season (days), respectively. We arbitrarily defined the growing season to coincide with the locally ice-free months of May through October, and used the average daily high temperature for this time period $\left(19.9^{\circ} \mathrm{C}\right)$ as $\mathrm{T}_{\mathrm{gs}}$. After calculating a value for $\log _{10}\left(\mathrm{P} / \mathrm{B}_{\mathrm{gs}}\right)$, one can solve for $\mathrm{P}$, by plugging in the estimated $\mathrm{B}_{\mathrm{gs}}$, based on our biomass estimates for each taxon category multiplied by the length of the growing season. The obtained pre- and post-invasion $\mathrm{P}_{\mathrm{gs}}$ values for each zooplankton species were summed into the broader cladoceran, cyclopoid copepod, and calanoid copepod groupings to obtain preand post-invasion total "Secondary Production" estimates. Post-invasion secondary production was then compared to pre-invasion secondary production to give us a preliminary estimate of declines.

\section{Laboratory induction experiments}

Prior studies established that small cladocerans, like Bosmina, undergo spine elongation and increased body size when placed in close proximity to many natural invertebrate predators (Kerfoot 1987; Kerfoot and McNaught 2010). The transmitting agent may be a chemical kairomone, since effects pass through nets on submersed bottles (Kerfoot and McNaught 2010; Kerfoot and Savage 2016), but may also involve physical stimulation (Sakamoto et al. 2007). When compared with Bythotrephes, Leptodora is similar in its handling responses, reduces small cladocerans, and induces spine elongation in Bosmina (McNaught et al. 2004; Kerfoot and McNaught 2010). Therefore, we anticipated that Bythotrephes should induce spine defenses in Bosmina.

For comparing Bosmina responses to Bythotrephes relative to an array of natural predators, we utilized a split clonal design (see Kerfoot 2006; Kerfoot and McNaught 2010). Bosmina stem females were netted (125 $\mu \mathrm{m}$ Nitex plankton net, towed vertically) from Portage Lake, Michigan, which is connected to Lake Superior. Individuals were transferred into finely filtered $(0.4 \mu \mathrm{m}$ Millipore $)$ and aged lake water (6 month old, refrigerated Portage Lake water) in $35 \mathrm{~mL}$ glass shell vials. Chlamydomonas reinhardii (U. Tex 90) was added as food each day, and medium changed every 2-3 weeks. Breeding parthenogenetically, stem females established clonal lines that grew exponentially. After a minimum of three generations (ca. 2 weeks) to purge maternal effects, a growing clone was split into two vials. The split-clonal design 
featured several advantages: (1) control and predatorexposed populations were genetically identical, (2) populations initially had similar demography, and (3) initial densities of prey (75-100 Bosmina/vial) were sufficient so that predators normally did not consume all prey during the limited time of exposure (7-12 days). In the small vial (35 mL) exposures, Bosmina liederi were tested against several known effective predators: the calanoids Epischura lacustris and Limnocalanus macrurus, and a suite of predatory cyclopoid copepods (Acanthocyclops vernalis, Mesocyclops edax), all known residents of Voyageurs' waters. For comparisons, Bythotrephes was introduced in similar fashion as an invasive predatory species. All the predators used in this experiment came from either Portage Lake or from Lake Superior. More details on experimental design, responses of Bosmina spp. from numerous geographic locations, and reactions to a larger variety of predators, can be found in Kerfoot and Savage (2016).

In the "predation" treatment, one of the split population vials received a single predator (e.g. advanced instar cyclopoid copepod Mesocyclops edax; calanoid copepod Epischura lacustris, small Bythotrephes), whereas the other split population vial served as a control. There was initial concern that large-bodied predators might consume high numbers of Bosmina and differentially deplete smaller instars. For this reason, predators were not acclimated to laboratory conditions. Moreover, confusion by large predators in the well-lit, relatively tight quarters of the $35 \mathrm{~mL}$ vials usually aided survival of prey, offsetting initial fears. However, additional concern that large predators might deplete oxygen in the small $35 \mathrm{~mL}$ vials caused us to use only immature stages of largerbodied predators. Vial exposures were run for 7-12 days, after which the entire vial contents were preserved. If predators died during the experiment, they were replaced (less than $20 \%$ of trials). If there was any evidence for major size-selective depletion of young during the exposure, the results were not included in tests. Tests were run on multiple clones.

All Bosmina were preserved in a $5 \%$ formalin solution to which $40 \mathrm{~g} \mathrm{L-1}$ of sucrose were added. Around 40 Bosmina were haphazardly removed from each plankton sample and mounted for measurement. Individuals were placed on a glass slide in a $50 \%$ glycerin-water mixture. Slides were covered with a glass cover-slip and measurements were made under a Leitz Wetzler compound microscope at 400X. Features measured on all individuals included: (1) total body length, (2) length of mucro (tail spine) from base to tip, and (3) length of antennule (anterior spine), measured from the proximal tooth (setae) to the distal tip. If the antennule was curved, measurements followed the curvature. Previous studies have established that the distribution of spine lengths closely resemble the normal distribution, although a positive relationship between the standard deviation and mean reveals an underlying log normal distribution (Kerfoot 1988). Moreover, spine length often remains nearly constant over body size, simplifying statistical comparisons (Kerfoot 1987; Kerfoot and McNaught 2010; Kerfoot and Savage 2016). Here mean spine elongation (predator treatment spine length—control length) from multiple "split-culture" experiments were compared using $t$ tests. For cross-comparisons, additional induction tests were performed on small-bodied Daphnia species, but these results are reported elsewhere.

\section{Results}

Pre-Bythotrephes assemblages

Pre-Bythotrephes pelagic microcrustacean sampling (2001-2003; Table 2) revealed a diverse assemblage of microcrustaceans (cladocerans and copepods), initially very similar to the above previously published accounts (e.g. Hargis et al. 1981). Some diaptomid and cyclopoid species occur throughout the winter in pelagic waters (e.g. Limnocalanus, Diaptomus sicilis, Acanthocyclops), whereas the majority of microcrustacean species emerge from diapausing eggs in spring, progressively adding species and individuals to the later-season communities. Extensive sampling in all the large lakes documented a pre-Bythorephes seasonal pattern of increasing biomass and biodiversity from spring to summer. Some species showed a preference for early-season cooler waters (the cladocerans Holopedium gibberum; the cyclopoid Diacyclops), whereas others preferred warmer summer waters (the cladocerans Diaphanosoma, Bosmina, Chydorus, Ceriodaphnia; the cyclopoid Mesocyclops). 
Table 2 Seasonal densities of taxa before and after Bythotrephes appearance (individuals/L $\pm 95 \%$ C.L.; $t$ test)

\begin{tabular}{|c|c|c|c|c|c|c|}
\hline \multirow[t]{2}{*}{ Species } & \multicolumn{2}{|l|}{ SPRING } & \multicolumn{2}{|l|}{ SUMMER } & \multicolumn{2}{|l|}{ FALL } \\
\hline & $\begin{array}{l}\text { Pre-invasion } \\
(\mathrm{N}=57)\end{array}$ & $\begin{array}{l}\text { Post-invasion } \\
(\mathrm{N}=65)\end{array}$ & $\begin{array}{l}\text { Pre-invasion } \\
(\mathrm{N}=62)\end{array}$ & $\begin{array}{l}\text { Post-invasion } \\
(\mathrm{N}=68)\end{array}$ & $\begin{array}{l}\text { Pre-invasion } \\
(\mathrm{N}=61)\end{array}$ & $\begin{array}{l}\text { Post-invasion } \\
(\mathrm{N}=61)\end{array}$ \\
\hline Holopedium gibberum & $0.55 \pm 0.29$ & $0.67 \pm 0.26$ & $0.66 \pm 0.26$ & $0.06 \pm 0.03 * * *$ & $0.11 \pm 0.11$ & $0.02 \pm 0.01$ \\
\hline Diaphanosoma birgei & $0.05 \pm 0.03$ & $0.03 \pm 0.02$ & $4.42 \pm 1.34$ & $0.42 \pm 0.28 * * *$ & $2.63 \pm 1.01$ & $0.03 \pm 0.05^{* * *}$ \\
\hline Daphnia mendotae & $0.60 \pm 0.37$ & $0.92 \pm 0.71$ & $1.69 \pm 0.74$ & $0.45 \pm 0.16^{* * *}$ & $3.49 \pm 1.56$ & $0.35 \pm 0.30^{* * *}$ \\
\hline Daphnia retrocurva & $0.33 \pm 0.27$ & $0.35 \pm 0.39$ & $2.58 \pm 1.92$ & $0.07 \pm 0.06^{* * *}$ & $3.77 \pm 2.45$ & $0.01 \pm 0.01 * * *$ \\
\hline Daphnia pulicaria & $0.66 \pm 0.89$ & $0.04 \pm 0.04 *$ & $0.37 \pm 0.49$ & $0^{* *}$ & $0.58 \pm 0.40$ & $0.15 \pm 0.25^{*}$ \\
\hline Bosmina spp. & $1.71 \pm 0.55$ & $1.35 \pm 1.05^{*}$ & $6.87 \pm 3.52$ & $0.37 \pm 0.21 * * *$ & $5.01 \pm 4.04$ & $0.33 \pm 0.27 * * *$ \\
\hline Chydorus spp. & $0.13 \pm 0.06$ & $0.02 \pm 0.02 * * *$ & $2.92 \pm 2.71$ & $0.01 \pm 0.01 * * *$ & $6.09 \pm 2.99$ & $0.01 \pm 0.01 * * *$ \\
\hline Ceriodaphnia spp. & $0.04 \pm 0.05$ & $0.03 \pm 0.02$ & $1.12 \pm 0.81$ & $0.01 \pm 0.01 * * *$ & $0.70 \pm 0.60$ & $0.01 \pm 0.01 * * *$ \\
\hline Mesocyclops edax & $0.35 \pm 0.13$ & $0.30 \pm 0.24$ & $1.60 \pm 0.35$ & $0.48 \pm 0.18 * * *$ & $1.51 \pm 0.35$ & $0.32 \pm 0.13^{* * *}$ \\
\hline Diacyclops bicusp. thomasi & $8.98 \pm 3.05$ & $6.81 \pm 2.30$ & $6.17 \pm 1.95$ & $0.50 \pm 0.17 * * *$ & $4.41 \pm 1.74$ & $0.21 \pm 0.08^{* * *}$ \\
\hline Tropocyclops prasinus & $0.20 \pm 0.11$ & $0.23 \pm 0.12$ & $1.22 \pm 0.52$ & $1.67 \pm 0.67$ & $1.72 \pm 0.58$ & $3.92 \pm 2.50$ \\
\hline Diaptomidae & $2.90 \pm 1.60$ & $2.45 \pm 0.93$ & $4.89 \pm 2.34$ & $2.75 \pm 0.81 * * *$ & $3.11 \pm 0.76$ & $2.11 \pm 0.48$ \\
\hline Nauplii and copepodites & $5.35 \pm 1.82$ & $6.88 \pm 2.53$ & $7.60 \pm 1.47$ & $4.26 \pm 1.19 * * *$ & $4.53 \pm 1.30$ & $1.32 \pm 0.61 * * *$ \\
\hline
\end{tabular}

Note density depressions for cladocerans, two of the three cyclopoid species, nauplii and the combined calanoid category, after Bythotrephes colonization. The decreases are evident in summer, and even carry over into fall (September-October), when diapausing eggs are produced. Samples come from "temporal sequence", significance levels $=* *^{*} p 0.05 ; * * p<0.01$; $* * * p<0.001$

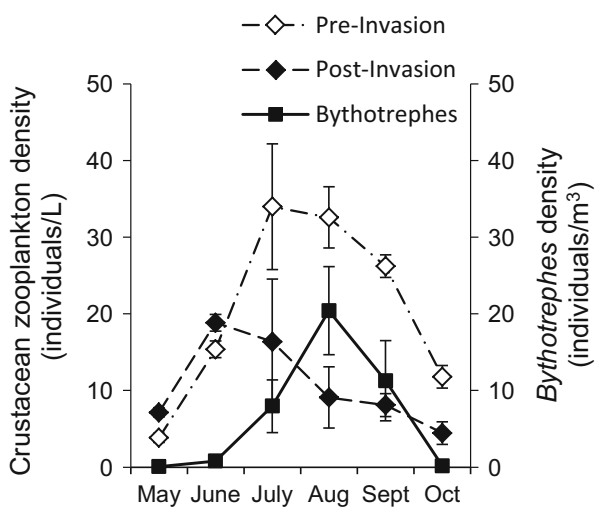

Fig. 4 Bythotrephes density maximum (mean \pm 1 SE) coincides with summer depression. Comparison of microcrustacean mean densities (dashed lines) in pre- and post-Bythotrephes samples from Lake Namakan. Bythotrephes density (solid line) is superimposed on the microcrustacean comparisons. Note how the decline in seasonal microcrustacean densities (dashed line) corresponds in time with the increase in Bythotrephes

\section{Post-Bythotrephes responses}

Bythotrephes was first detected in 2007. Invasion by Bythotrephes dramatically changed the overall seasonal density patterns (Fig. 4). In Fig. 4, the summer density pattern for Bythotrephes (solid line) is superimposed on the pre- and post-Bythotrephes total microcrustacean density patterns (dashed lines; example from Namakan Lake). The seasonal timing of the microcrustacean decline coincides with the increase in Bythotrephes density. Severe depression of cladoceran species extends into the fall, when diapausing eggs are produced (Table 2). Nauplii and early immature copepods also show significant declines in summer and fall samples (Table 2). Since Bythotrephes does not become abundant in the water column until late June, the early spring pattern shows less suppression than the summer and fall assemblages. However, eventually we expect a carry-over in spring as recruitment begins to show effects from a depleted egg bank. A few species (D. pulicaria, Bosmina spp., Chydorus) already exhibited significant declines in spring (Table 2).

Spatial contrast: comparison of prey in highdensity versus low-density Bythotrephes lakes

Based on the density of Bythotrephes in 2009-2010, we divided the lakes into two categories (Fig. 3), one 
in which Bythotrephes was relatively abundant (24.2-33.0 individuals $\mathrm{m}^{-3}$; Kabetogama, Namakan, Rainy) and the other in which Bythotrephes was relatively scarce (0.3-5.7 individuals $\mathrm{m}^{-3}$; Sand Point, Crane, Little Vermilion; see "Methods"). The spatial comparison contrasted differences between the two categories of lakes during 2009-2010. Effects on the microcrustacean assemblage were both general and taxon-specific.

There were major microcrustacean differences between low- and high-density Bythotrephes lakes (Fig. 5a; Table 3). Filter-feeding cladocerans suffered the greatest reductions in density, with some of the smaller-bodied species the most depressed. Significant differences are indicated by asterisks. ANOVA ( $d f$ $1 / 42$ ) tests indicated that significantly reduced taxa in high-density Bythotrephes lakes included Diaphanosoma $\left(\mathrm{F}=54.3, p=4.3 \times 10^{-9}\right)$, Daphnia mendotae $\left(\mathrm{F}=23.6, p=1.7 \times 10^{-5}\right), D$. retrocurva $(\mathrm{F}=6.3, p=0.02), D$. longiremis $(\mathrm{F}=8.9, p=$ $\left.4.7 \times 10^{-3}\right)$, and Bosmina $(\mathrm{F}=28.4, p=3.6 \times$ $\left.10^{-6}\right)$. Diaphanosoma fell from a density of 11.8 individuals $\mathrm{L}^{-1}$ in low-Bythotrephes lakes to a low of 0.2 individuals $\mathrm{L}^{-1}$ in high-Bythotrephes lakes.
Fig. 5 Zooplankton community shifts in Spatial Contrast lakes (high vs low Bythotrephes): a Species densities are plotted on an arithmetic scale in lowBythotrephes (white) and high-Bythotrephes (black) lakes (mean $\pm 1 \mathrm{SE}$ ). Significance noted to right of bars $\left(p<0.05^{*}\right.$; $\left.p<0.01^{* *} ; p<0.001^{* * *}\right)$. b Corresponding biomass densities are plotted on a logarithmic scale; comparing lowBythotrephes (white) and high-Bythotrephes (black) lakes, with significance levels as above (mean \pm 1 $\mathrm{SE})$

\section{a}

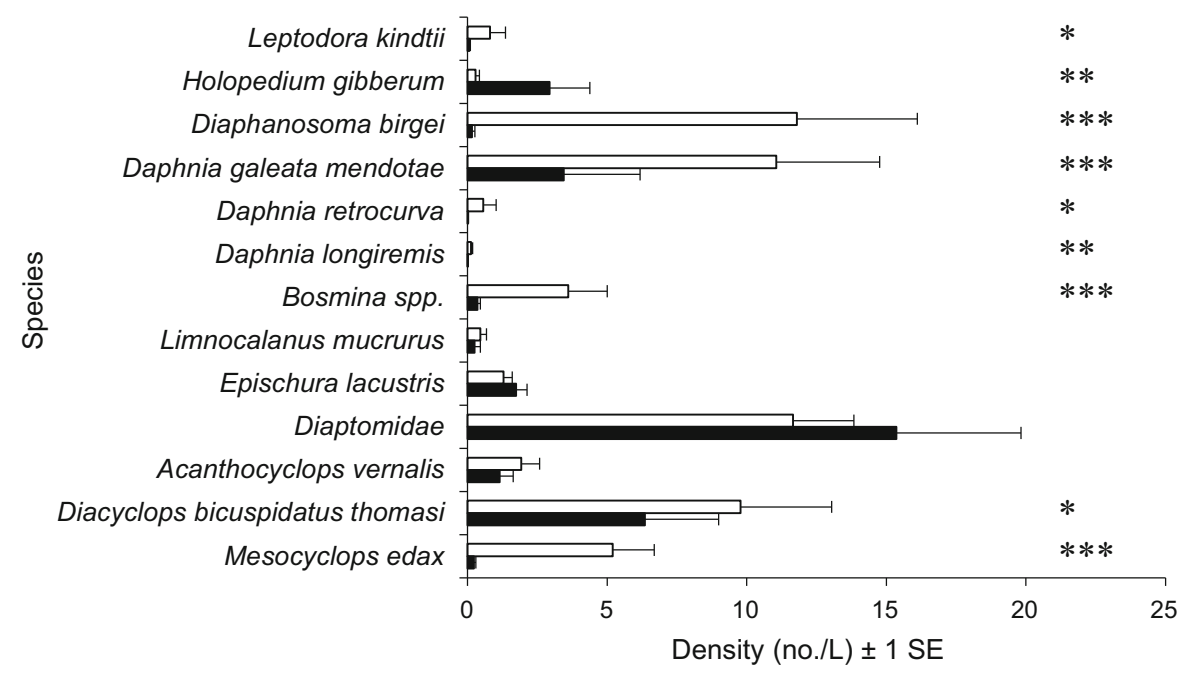

b

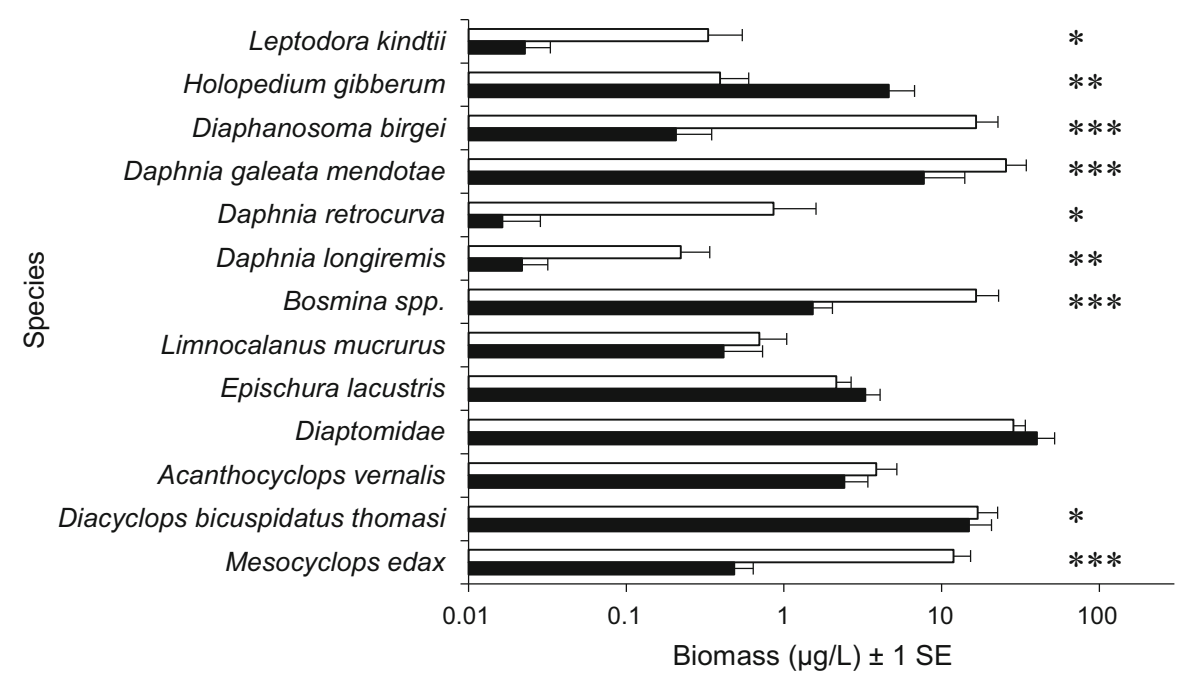


Table 3 One-way ANOVA for Spatial Contrast (2009-2010 summer samples), on biomass of taxa between high- and lowBythotrephes lakes $(d f=1$ between groups, 24 within groups, significance levels $=* p<0.05 ; * * p<0.01 ; * * * p<0.001$ )

\begin{tabular}{|c|c|c|c|c|c|c|c|}
\hline \multirow[t]{2}{*}{ Taxa } & \multicolumn{2}{|c|}{ Density (No./L) } & \multicolumn{2}{|c|}{ Biomass $(\mu \mathrm{g} / \mathrm{L})$} & \multirow[t]{2}{*}{$\mathrm{F}$} & \multicolumn{2}{|l|}{ ANOVA } \\
\hline & Low Bytho & High Bytho & Low Bytho & High Bytho & & $p$ value & Significance* \\
\hline Leptodora kindtii & 0.80 & 0.07 & 0.33 & 0.02 & 5.27 & 0.03 & Decrease* \\
\hline Holopedium gibberum & 0.29 & 2.94 & 0.39 & 4.64 & 6.48 & 0.01 & Increase $* *$ \\
\hline Diaphanosoma birgei & 11.80 & 0.15 & 16.57 & 0.21 & 54.26 & $4.3 \times 10^{-9}$ & Decrease $e^{* * *}$ \\
\hline Daphnia mendotae & 11.05 & 3.45 & 25.67 & 7.73 & 23.60 & $1.7 \times 10^{-5}$ & Decrease $* * *$ \\
\hline Daphnia retrocurva & 0.56 & 0.02 & 0.86 & 0.02 & 6.26 & 0.02 & Decrease* \\
\hline Daphnia longiremis & 0.12 & 0.01 & 0.22 & 0.02 & 8.91 & $4.7 \times 10^{-3}$ & Decrease $^{* *}$ \\
\hline Bosmina spp. & 3.60 & 0.35 & 16.52 & 1.53 & 28.43 & $3.6 \times 10^{-6}$ & Decrease $^{* * *}$ \\
\hline Limnocalanus mucrurus & 0.45 & 0.25 & 0.70 & 0.42 & 2.22 & 0.14 & No change \\
\hline Epischura lacustris & 1.29 & 1.73 & 2.15 & 3.29 & 0.02 & 0.90 & No change \\
\hline Diaptomidae & 11.65 & 15.36 & 28.51 & 40.28 & 0.39 & 0.53 & No change \\
\hline Acanthocyclops vernalis & 1.92 & 1.14 & 3.85 & 2.42 & 2.93 & 0.09 & No change \\
\hline Diacyclops thomasi & 9.77 & 6.35 & 16.97 & 14.90 & 4.10 & 0.05 & Decrease* \\
\hline Mesocyclops edax & 5.20 & 0.23 & 11.91 & 0.48 & 60.91 & $1.1 \times 10^{-8}$ & Decrease $* * *$ \\
\hline All Cladocerans & & & 60.58 & 14.17 & $76.6 \%$ decrease & & \\
\hline All Copepods & & & 64.08 & 61.78 & $3.6 \%$ decrease & & \\
\hline Total & & & 124.65 & 75.95 & $39.1 \%$ decrease & & \\
\hline
\end{tabular}

Density (No./L) values also provided (left), as well as decreases for collective categories (below)

Daphnia g. mendotae fell from 11.1 individuals $\mathrm{L}^{-1}$ in low-Bythotrephes lakes to 3.5 individuals $\mathrm{L}^{-1}$ in highBythotrephes lakes. The predatory cladoceran Leptodora was also significantly reduced, declining from 0.8 individuals $\mathrm{L}^{-1}$ in low-Bythotrephes lakes to 0.1 individuals $\mathrm{L}^{-1}$ in high-Bythotrephes lakes $(\mathrm{F}=5.3$, $p=0.03)$. In the Spatial Contrast, only one cladoceran taxon other than Bythotrephes increased in density, and that was the cladoceran Holopedium. Holopedium density increased significantly $(\mathrm{F}=6.5$, $p=0.01$ ) from 0.3 to 2.9 individuals $\mathrm{L}^{-1}$. Because of variance due to clumping, without the long horizontal net tows, that increase would have been difficult to demonstrate statistically.

Among the copepods (Fig. 5a), cyclopoid taxa generally decreased in density, whereas a few calanoid categories increased. The cyclopoid Mesocyclops edax decreased significantly $(\mathrm{F}=60.9, p=1.1 \times$ $10^{-8}$ ) in density from 5.2 to 0.2 individuals $\mathrm{L}^{-1}$, whereas Diacyclops thomasi decreased significantly $(\mathrm{F}=4.1, p=0.05)$ in density from 9.8 to 6.4 individuals $\mathrm{L}^{-1}$. The remaining tallied cyclopoid (Acanthocyclops vernalis) declined from 1.9 to 1.1 individuals $\mathrm{L}^{-1}$, but the decline was not significant.
Calanoid copepods (the combined category Diaptomidae; Epischura lacustris, Limnocalanus mucrurus) increased slightly (12-15 individuals $\mathrm{L}^{-1}$ ), but again these changes were not significant. In contrast, although not included as a category in Fig. 5 or in Table 3, nauplii and young copepodites suffered a significant decrease from 11.2 to 6.9 individuals $\mathrm{L}^{-1}$ $(\mathrm{F}=5.5, p=0.02)$. To view the relative decreases in biomass, differences for species are plotted separately on a logarithmic scale in Fig. 5b. The graph emphasizes that many species were still present after Bythotrephes colonization, yet at 1/100th their original densities. Whether the species persisted at low levels because of continuing recruitment from egg banks could not be determined, but the decreases were substantial.

Was there any evidence for reciprocity? That is, how much biomass increase occurred versus decrease? Holopedium increased from $0.3 \%$ of microcrustacean biomass in low-Bythotrephes lakes to $5.7 \%$ in highBythotrephes lakes. The Spatial Contrast recorded a biomass increase of $4.25 \mu \mathrm{g} \mathrm{L}^{-1}$ for Holopedium (i.e., low-Bythotrephes lakes had only a mean biomass of $0.39 \mu \mathrm{g} \mathrm{L}^{-1}$, whereas high-Bythotrephes lakes had a 
mean biomass of $4.64 \mu \mathrm{g} \mathrm{L}^{-1}$ ). The only other significantly increasing species, Bythotrephes, had a biomass of $0.46 \mu \mathrm{g} \mathrm{L}^{-1}$ in high-Bythotrephes lakes, compared to $0.02 \mu \mathrm{g} \mathrm{L}^{-1}$ in low-Bythotrephes lakes. Combining Bythotrephes plus Holopedium biomass gives a $4.7 \mu \mathrm{g} \mathrm{L}^{-1}$ biomass increase compared to the total microcrustacean decrease of $54.2 \mu \mathrm{g} \mathrm{L}^{-1}$. That is, given the significant increases and decreases, the differences do not appear balanced, i.e. reciprocal. However, the biomass of diaptomid copepods increased from 28.5 to $40.3 \mu \mathrm{g} \mathrm{L}^{-1}$, a difference of $11.8 \mu \mathrm{g} \mathrm{L}^{-1}$, which could be important. That is, filterfeeding calanoids could be replacing a portion of the depressed filter-feeding cladocerans.

\section{Temporal contrast}

The Temporal Contrast data were derived from an independent set of vertical plankton hauls that extended over a much greater interval of time, from 2001 until 2010. Not surprisingly, comparison of postinvasion with pre-invasion densities and biomass in Kabetogama, Namakan, and Rainy Lakes also documented differences in the microcrustacean community. Again there were major, similar differences among densities and biomass for different taxa (Fig. 6; Table 4).

The long-term temporal data set documented similar, but perhaps even more pervasive summer changes across the zooplankton community (Fig. 6; Table 4). Greater resolution came from the larger number of samples, emphasis on the 3 large lakes, and restriction to summer samples (see Methods). In Fig. 6, biomass differences are again plotted on a logarithmic scale. In the Temporal Contrast, again almost all filter-feeding cladoceran species were depressed in post-invasion samples compared to preinvasion conditions. One-way ANOVA $(d f=1 / 232)$ documented significance (Table 4): Diaphanosoma $\left(\mathrm{F}=27.5, \quad p=3.6 \times 10^{-7}\right), \quad$ Daphnia mendotae $(\mathrm{F}=5.6, \quad p=0.02), \quad$ D. retrocurva $\quad(\mathrm{F}=8.7$, $\left.p=3.4 \times 10^{-3}\right)$, D. pulicaria $(\mathrm{F}=5.5, p=0.02)$, Bosmina $(\mathrm{F}=5.5, p=0.02)$, Eubosmina $(\mathrm{F}=8.7$, $\left.p=3.4 \times 10^{-3}\right)$, Chydorus $(\mathrm{F}=6.5, p=0.01)$, and Ceriodaphnia $(\mathrm{F}=5.2, p=0.02)$. In the Temporal Contrast series, two larger-bodied taxa [Leptodora $(\mathrm{F}=0.1, \quad p=0.75)$ and Holopedium $(\mathrm{F}=2.6$, $p=0.11)$ ] did not change significantly.

Among cyclopoids, Mesocyclops ( $\mathrm{F}=20.6$, $\left.p=9.2 \times 10^{-6}\right)$ and Diacyclops $(\mathrm{F}=8.7, p=3.5$ $\times 10^{-3}$ ) decreased significantly, whereas Tropocyclops

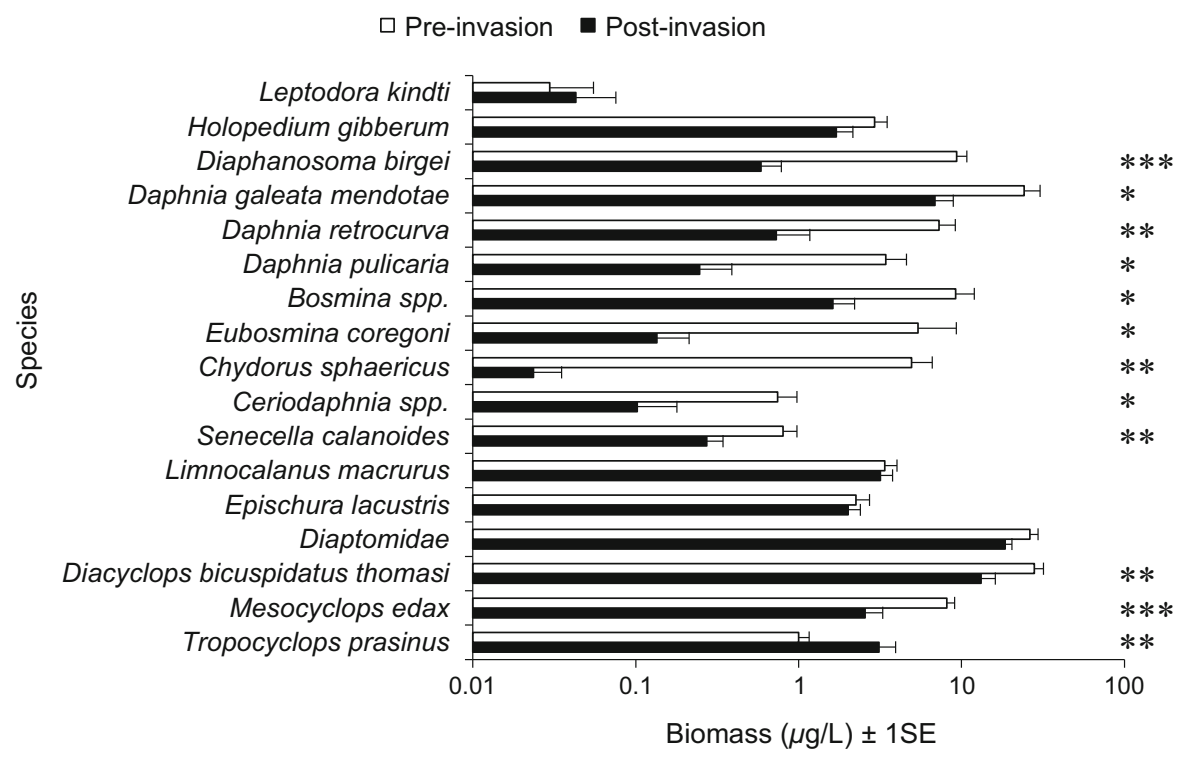

Fig. 6 Zooplankton community shifts in Temporal Contrast (before vs after Bythotrephes). Species densities before (white) and after (black) Bythotrephes in three lakes (Rainy, Namakan, Kabetogama). Biomass scale is logarithmic with significance levels $\left(p<0.05^{*} ; p<0.01^{* *} ; p<0.001^{* * *}\right)$ to right of the taxon category (mean \pm 1 SE). White corresponds to 2001-2003 biomass (i.e. pre-Bythotrephes), whereas black corresponds to 2007-2010 biomass (post-Bythotrephes) 
Table 4 One-way ANOVA results for Temporal Contrast on selected taxa biomass $(d f=1$ between groups, 203 within groups; significance $=* p<0.05 ; * * p<0.01 ; * * * p<0.001)$

\begin{tabular}{|c|c|c|c|c|c|c|c|}
\hline \multirow[t]{2}{*}{ Taxa } & \multicolumn{2}{|c|}{ Density (No./L) } & \multicolumn{2}{|c|}{ Biomass $(\mu \mathrm{g} / \mathrm{L})$} & \multirow[t]{2}{*}{$\mathrm{F}$} & \multicolumn{2}{|l|}{ ANOVA } \\
\hline & $\begin{array}{l}\text { Pre- } \\
\text { invasion }\end{array}$ & $\begin{array}{l}\text { Post- } \\
\text { invasion }\end{array}$ & $\begin{array}{l}\text { Pre- } \\
\text { invasion }\end{array}$ & $\begin{array}{l}\text { Post- } \\
\text { invasion }\end{array}$ & & $p$ value & Significance* \\
\hline Leptodora kindtii & 0.02 & 0.02 & 0.03 & 0.04 & 0.11 & 0.75 & No change \\
\hline Holopedium gibberum & 2.25 & 0.88 & 2.92 & 1.70 & 2.57 & 0.11 & No change \\
\hline Diaphanosoma birgei & 6.44 & 0.75 & 9.34 & 0.59 & 27.46 & $3.6 \times 10^{-7}$ & Decrease $* * *$ \\
\hline Daphnia mendotae & 17.39 & 6.77 & 24.27 & 6.86 & 5.55 & 0.02 & Decrease* \\
\hline Daphnia retrocurva & 5.00 & 0.09 & 7.29 & 0.73 & 8.74 & $3.4 \times 10^{-3}$ & Decrease $^{* *}$ \\
\hline Daphnia pulicaria & 1.68 & 0.06 & 3.43 & 0.25 & 5.46 & 0.02 & Decrease* \\
\hline Bosmina spp. & 6.14 & 0.63 & 9.22 & 1.62 & 5.46 & 0.02 & Decrease* \\
\hline Eubosmina spp. & 3.79 & 0.10 & 5.42 & 0.13 & 8.71 & $3.4 \times 10^{-3}$ & Decrease ${ }^{* *}$ \\
\hline Chydoris sphaericus & 2.94 & 0.02 & 4.94 & 0.02 & 6.48 & 0.01 & Decrease ${ }^{* *}$ \\
\hline Ceriodaphnia spp. & 0.59 & 0.06 & 0.74 & 0.10 & 5.16 & 0.02 & Decrease* \\
\hline Senecella calanoides & 0.40 & 0.15 & 0.80 & 0.27 & 6.22 & 0.01 & Decrease* \\
\hline Limnocalanus mисrurus & 2.99 & 2.68 & 3.38 & 3.18 & 0.05 & 0.82 & No change \\
\hline Epischura lacustris & 0.87 & 1.38 & 2.25 & 2.01 & 0.14 & 0.71 & No change \\
\hline Diaptomidae & 13.43 & 10.36 & 26.28 & 18.54 & 3.76 & 0.06 & No change \\
\hline Acanthocyclops vernalis & 0.55 & 0.01 & 0.35 & 0.00 & 1.05 & 0.31 & No change \\
\hline $\begin{array}{l}\text { Diacyclops bicuspidatus } \\
\text { thomasi }\end{array}$ & 12.78 & 8.99 & 28.04 & 13.21 & 8.70 & $3.5 \times 10^{-3}$ & Decrease $^{* *}$ \\
\hline Mesocyclops edax & 4.93 & 1.73 & 8.14 & 2.56 & 20.56 & $9.2 \times 10^{-6}$ & Decrease*** \\
\hline Tropocyclops prasinus & 0.79 & 1.61 & 1.00 & 3.11 & 8.40 & $4.1 \times 10^{-3}$ & Increase ${ }^{* *}$ \\
\hline All cladocerans & & & 67.605 & 12.05 & $\begin{array}{l}82.2 \% \\
\text { decrease }\end{array}$ & & \\
\hline All copepods & & & 70.23 & 42.88 & $\begin{array}{l}38.9 \% \\
\text { decrease }\end{array}$ & & \\
\hline Total & & & 137.83 & 54.93 & $\begin{array}{l}60.1 \% \\
\text { decrease }\end{array}$ & & \\
\hline
\end{tabular}

Density (No./L) given in left columns. Reductions for collective categories (cladocerans, copepods) are given below taxa

increased significantly $\left(\mathrm{F}=8.4, \quad p=4.1 \times 10^{-3}\right)$. Among large-bodied hypolimetic calanoid species, the glacial relict species Senecella calanoides $(\mathrm{F}=6.2$, $p=0.01)$ decreased after Bythotrephes invasion, although the other glacial relict, Limnocalanus macrurus, did not. None of the other calanoid copepods (Diaptomidae, Epischura) and the one remaining cyclopoid (Acanthocyclops; F $=1.0, p=0.31$ ) had significant differences. However, again nauplii and early copepodites decreased significantly in biomass from 5.0 to $3.8 \mu \mathrm{g} \mathrm{L}^{-1}(\mathrm{~F}=3.8 ; p=0.02)$. Seasonal comparisons (summer, fall) of nauplii and early copepodites were also significant (Table 2). ANOVA was run separately on Sand Point Lake, to check pre-2007 versus post-2007 densities in a lake where Bythotrephes were at low, but increasing, densities (Table 3). Densities for cladoceran taxa were slightly lower, but not significant $(\mathrm{F}=2.62, p=0.11)$.

As for reciprocal responses in biomass, if overall gains are compared to losses, gains amounted to only a $2.1 \mu \mathrm{g} \mathrm{L}^{-1}$ gain versus a $84.1 \mu \mathrm{g} \mathrm{L}^{-1}$ loss. Although species responses were very similar to the Spatial Contrast, calanoid copepods here posted a $8.7 \mu \mathrm{g} \mathrm{L}^{-1}$ decline in total biomass. Thus in this comparison, there was even less evidence for filter-feeding calanoids increasing to fill a gap left by depressed filter-feeding cladocerans, and strong evidence that both cyclopoids and calanoids were mutually depressed. 
Principal components analysis of spatial and temporal patterns

A Principal Components Analysis (PCA) of the correlation matrix of species' biomass, run on Spatial Contrast and Temporal Contrast data sets, helped clarify species' responses. A factor loadings plot of microcrustacean responses for the Spatial Contrast data is shown in Fig. 7a. Of twelve variables (corresponding to the twelve species' categories), only four latent roots (eigenvalues) fell above $1.00(1=5.14$, $2=1.77,3=1.63,4=1.22$; where 1.00 is a random spread). The total variance explained in the Spatial Contrast PCA analysis was high (71.2\% Variance). Factor 1 was by far the most important axis $(42.9 \%$ Variance), weighted primarily by strong positive and negative biomass shifts. There was a clear cluster of filter-feeding cladocerans (Diaphanosoma, Daphnia, Bosmina), omnivorus copepods (Mesocyclops, Diacyclops), and one predatory cladoceran (Leptodora) that represent taxa strongly reduced in density by Bythotrephes. Along the opposite axis direction of Factor 1, there were strong loadings for the two species (Bythotrephes, Holopedium) that show positive increases in density. Between the two extreme clusters lie two calanoid copepods with weaker positive density responses (Epischura, Diaptomidae), and two additional copepods with weak density declines (Acanthocyclops, Limnocalanus). Factors 2 and 3 more strongly separated out the latter two clusters, the first two positive and the last two more strongly negative. Recall that Bythotrephes is largely epilimnetic, whereas the latter clusters with hypolimnetic species (some Diaptomidae, Limnocalanus) could be illustrating weak, independent fluctuations.

A 3-dimensional PCA plot for the summer-season, Temporal Contrast correlation matrix was similar (Fig. 7b), but explained less total variance, about $50 \%(49.7 \%)$. Again, positive and negative biomass responses dominated clustering. The first $(25.5 \%$ variance) and third (10.4\% variance) factors separated species depressed by Bythotrephes (a cluster of cladocerans Diaphanosoma, Bosmina, Chydorus, Daphnia retrocurva, D. mendotae; $D$. pulicaria; the copepods Mesocyclops edax and Diacyclops), whereas the opposite extreme along the axis clusters species showing biomass increases associated with Bythotrephes (Tropocyclops, and Epischura). The third cluster contained Scenecella and Limnocalanus, both cold-water, hypolimnetic calanoid copepods. Neither of the latter species occurs directly with Bythotrephes in epilimnetic waters, thus the latter correlations may again represent independent effects.

Density shifts in spring-fall seasonal patterns

Comparing pre- with post-Bythotrephes assemblages in the larger lakes (Fig. 8), the late summer cladoceran peak that was so characteristic of Kabetogama, Namakan, and Rainy Lakes prior to Bythotrephes completely disappeared. Using Rainy Lake as an example, the pre-Bythotrephes pattern of low total zooplankton density in spring (e.g. 5-20 organisms $\mathrm{L}^{-1}$ ) was followed by a late-summer to early fall maximum density peak (60-150 organisms $\mathrm{L}^{-1}$ ). After Bythotrephes, summer and early fall densities fell below 20 organisms $\mathrm{L}^{-1}$. All three large lakes showed similar biomass shifts. After Bythotrephes colonization, the late-season reduction in total zooplankton density was so pronounced that the relative seasonal pattern reversed. Zooplankton in Bythotrephes lakes were now more abundant in spring (15-60 organisms $\mathrm{L}^{-1}$ ) than in summer (5-20 organisms $\mathrm{L}^{-1}$ ).

Biomass, secondary production, and diversity comparisons

In the Spatial Contrast, biomass and diversity were influenced by Bythotrephes abundance (Fig. 9; Table 3). In low-density Bythotrephes lakes, the biomass of microcrustaceans averaged $135.6 \pm 6.2 \mu \mathrm{g} \mathrm{L}^{-1}$. Of that total, cladocerans amounted to $60.6 \pm 9.5 \mu \mathrm{g} \mathrm{L}^{-1}(45 \%)$ and copepods $75 \pm 4.4 \mu \mathrm{g} \mathrm{L}^{-1}(55 \%)$. Within high-Bythotrephes lakes, total biomass fell to $81.4 \mu \mathrm{g} \mathrm{L}^{-1}$. Of that total, cladocerans declined to a biomass of only $14.2 \pm 1.1 \mu \mathrm{g} / \mathrm{L}(17 \%)$, whereas copepods made up a biomass of $67.3 \pm 6.4 \mu \mathrm{g} / \mathrm{L}(83 \%)$. Cladocerans and certain species of cyclopoid copepods were reduced, as the assemblage moved relatively towards calanoid copepods. For late summer, the ShannonWiener Index (H') of diversity was 1.98 in low-density Bythotrephes lakes compared to 1.22 in high-density Bythotrephes lakes ( $t$ test; $p=0.035^{*}$ ). Reduced density of cladoceran and copepod taxa contributed to the decline in the index.

In the Temporal Contrast series (Fig. 9; Table 4), biomass plots again emphasize the severe losses 
Fig. 7 Principle Component Analysis (PCA) of: a Summer Spatial Contrast correlation matrix of biomass values. Taxa positions are given relative to the three component axes (Factors 1-3). Percent variance explained by each factor loading is shown in the bottom of figure.

b Temporal Contrast correlation matrix of biomass values. Taxa positions are given relative to the three component axes (Factors 1-3). Percent variance explained by each factor loading is given at the bottom of figure. Size of the circle helps indicate which species cluster is close (i.e. larger) rather than distant (smaller)
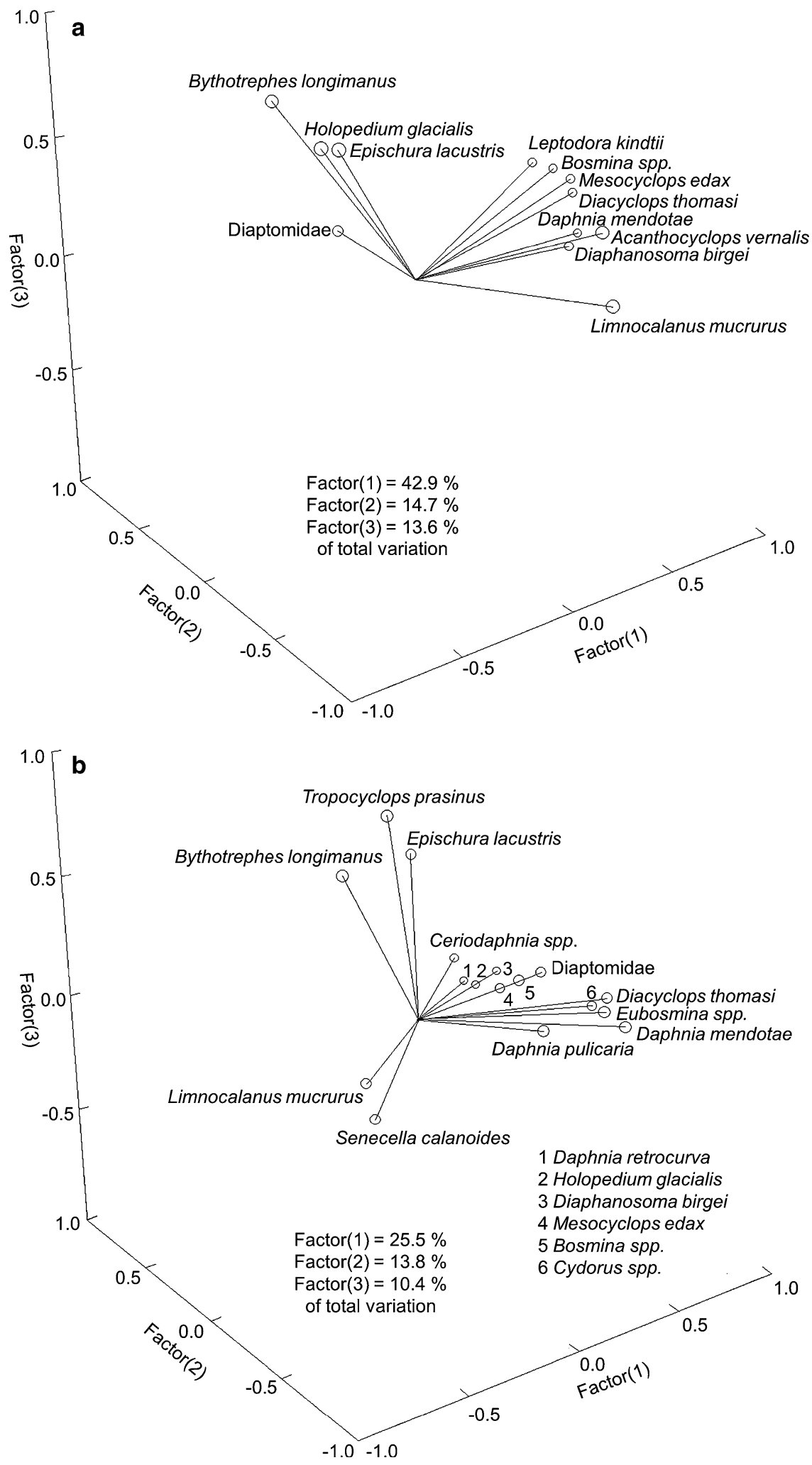
among cladoceran species, but also accumulative losses in copepod species. Pre-invasion total biomass was $142.9 \mu \mathrm{g} \mathrm{L}^{-1}$, of which $67.6 \mu \mathrm{g} \mathrm{L}^{-1}(47 \%)$ was cladoceran and $75 \mu \mathrm{g} \mathrm{L}^{-1}$ (52\%) was copepod, very close to the low-density Spatial Contrast tallies. In post-Bythotrephes samples, total mean biomass was reduced to $59 \pm 1.2 \mu \mathrm{g} \mathrm{L}^{-1}$ (60\% reduction), with a corresponding $12 \pm 0.7 \mu \mathrm{g} \mathrm{L}^{-1}$ (82\% reduction) for cladoceran biomass and $47 \pm 2.6 \mu \mathrm{g} \mathrm{L}^{-1}(38 \%$ reduction) for copepod biomass. After Bythotrephes, cladocerans made up only $20.5 \%$ of the microcrustacean biomass, whereas copepods made up $79.5 \%$ of the microcrustacean biomass. Again, on a relative basis the assemblage moved strongly towards calanoid copepods. Mid-summer diversity also declined as the Shannon-Weiner Index of diversity fell from 2.26 to 1.81 ( $t$ test; $p=0.015^{*}$ ).

As discussed in the Methods, changes in secondary production were estimated using the following model from Shuter and Ing (1997): $\log _{10}\left(\mathrm{P} / \mathrm{B}_{\mathrm{gs}}\right)=$ $\alpha+\beta\left(\mathrm{T}_{\mathrm{gs}}\right)+\Phi\left(\log _{10}(\mathrm{gs})\right)$, where $\mathrm{P} / \mathrm{B}_{\mathrm{gs}}$ is the ratio of secondary production (P) to biomass (B) over the growing season for a specific taxon (i.e. cladocerans, cyclopoid copepods, or calanoid copepods), $\alpha, \beta$, and $\Phi$ are constants, with $\alpha$ being distinct for each of the three taxa (cladocerans, -1.725 ; cyclopoid copepods, -1.766 ; and calanoid copepods, -2.458). Corresponding estimates for B were: cladocerans 0.044; cyclopoids, 0.040 , and calanoids 0.050$)$. The variables $\mathrm{T}_{\mathrm{gs}}$ and gs refer to daily temperature $\left({ }^{\circ} \mathrm{C}\right)$ over the growing season, and the total length of the growing season (days), respectively. The growing season was estimated as 215 days. Annual production was the product of three distinct variables: the average daily weight-specific production rate, the average biomass over the growing season, and the length of the growing season. Pre-invasion production for all microcrustaceans (cladoceran, cyclopoid, and calanoid taxa) was estimated at $744 \mathrm{~g} / \mathrm{m}^{3} /$ year, whereas post-invasion production was estimated at $245 \mathrm{~g} / \mathrm{m}^{3} /$ year. The difference amounted to a reduction of $67 \%$. The pronounced production decline was largely attributable to serious biomass losses (B) during the warm summer months of cladoceran taxa plus the longer lifespans of calanoid and cyclopoid copepods relative to cladocerans. To underscore how changing community differences influence production values, median $\mathrm{P} / \mathrm{B}_{\mathrm{gs}}$ values for cladocerans and calanoids from Shuter and Ing (1997) were estimated as 0.16 and
0.04 , respectively, indicating a four-fold difference between cladocerans and calanoids.

\section{Laboratory induction experiments}

Tests with co-occurring natural predators showed that spines responded strongest to the calanoid copepod Epischura and to an assortment of predatory calanoid copepod and cyclopoid copepods know to commonly co-occur with, and be effective predators on, Bosmina. Responses were greatest to Epischura, although increases in mucro (posterior spine) and antennule (anterior spine) lengths were intermediate in a suite of cyclopoid and calanoid copepods (Limnocalanus, Mesocyclops, Acanthocyclops). When mean responses (Fig. 10) are plotted, Bosmina failed to respond significantly in mucro and antennule length to the exotic species Bythotrephes (mucro $d f=1121$; $\mathrm{F}=0.162, p=0.69 ;$ antennules $d f=1121, \mathrm{~F}=$ $2.83, p=0.10)$. Whereas these preliminary experiments tested only Bosmina liederi, they clearly show that this small cladoceran is not enlarging defensive spines against the invasive Bythotrephes, increasing its susceptibility to predation. The results suggest that some prey species may not perceive the predator's presence and are "blind-sided" by the predator.

\section{Discussion}

Because of its size, the Voyageurs Park study allowed for two separate comparisons, a spatial and a temporal. Results of the two comparisons were basically similar, i.e. severe depression of summer cladoceran populations and certain cyclopoid taxa in summer and early fall. As compared to other small and large lake studies, we clearly show that effects are large enough to strongly influence basic seasonal patterns of microcrustacean biomass and secondary productivity. Typically early spring assemblages of calanoid and cyclopoid copepods transition into more dense summer assemblages of mixed copepods and cladocerans. Bythotrephes not only halved normal summer densities, it reversed the seasonal density pattern, severely reducing late season cladoceran density and biomass. Summer biodiversity was decreased, as lake assemblages were pushed more towards a mixture of calanoid copepod species. 
Pre-invasion (2001-2003)

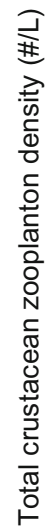

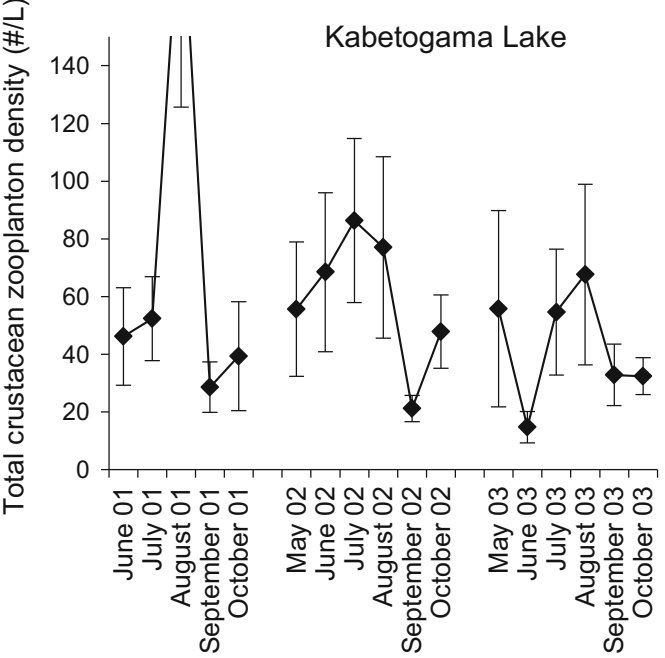

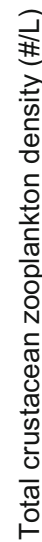
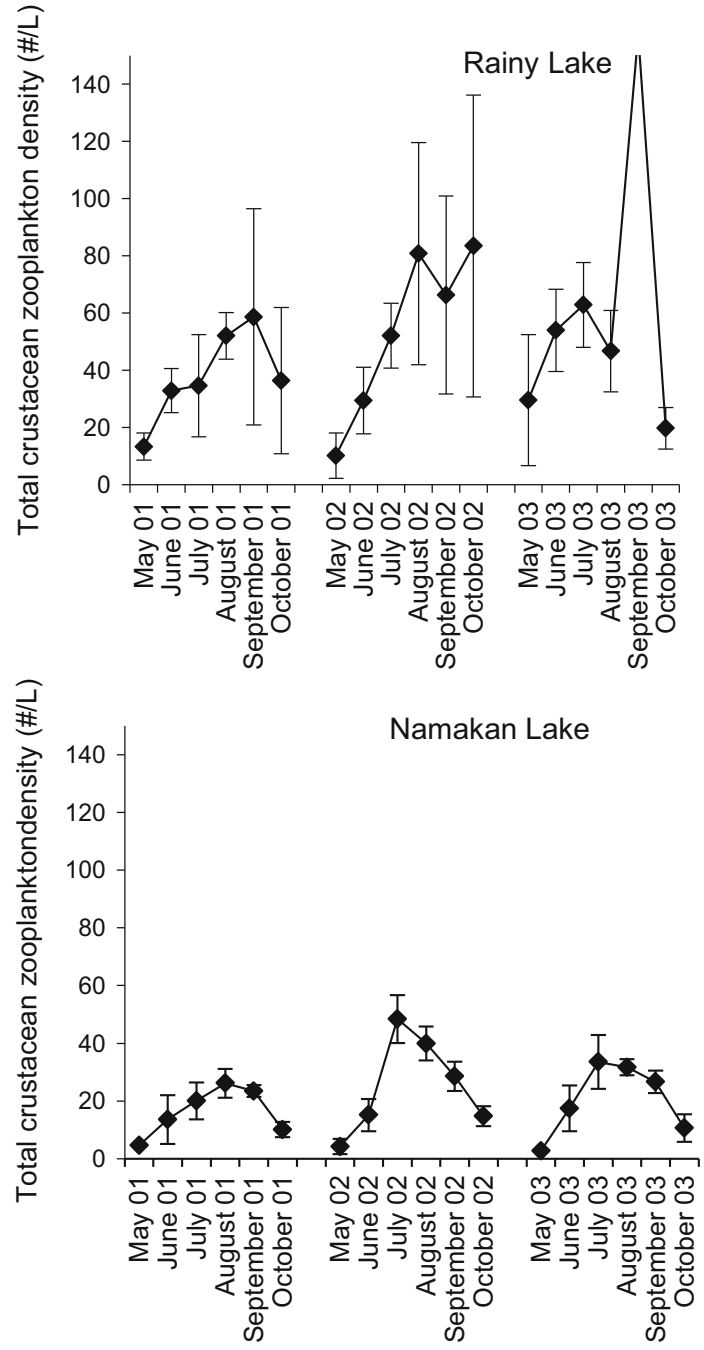

Post-invasion (2007-2010)

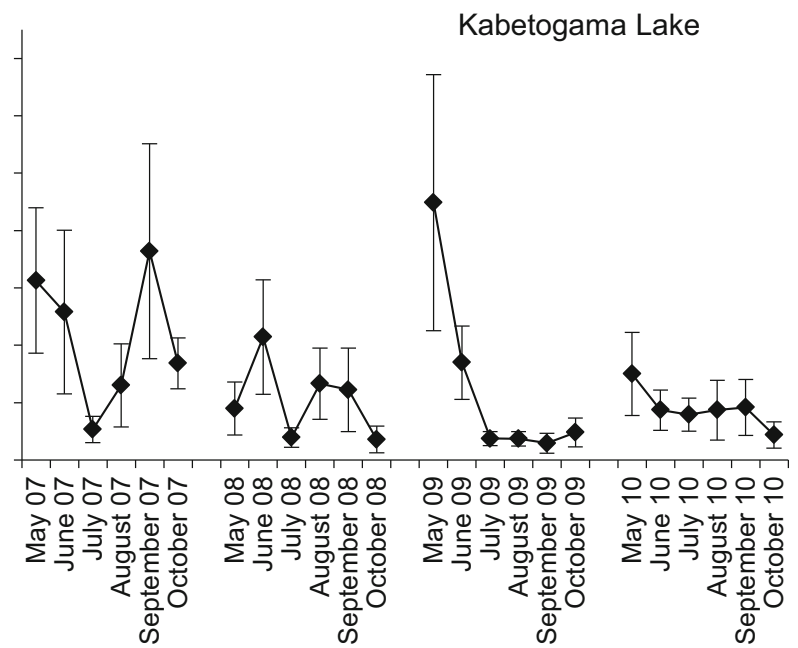

Rainy Lake

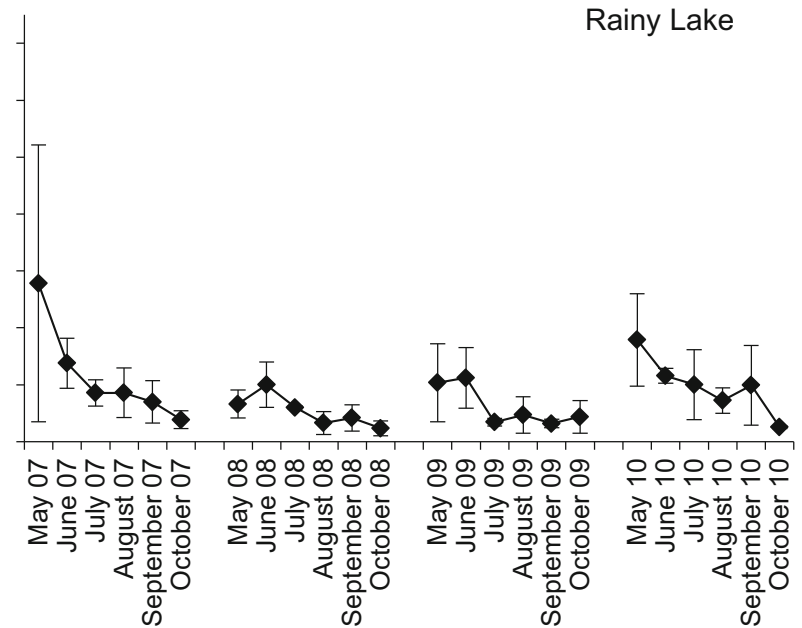

Namakan Lake

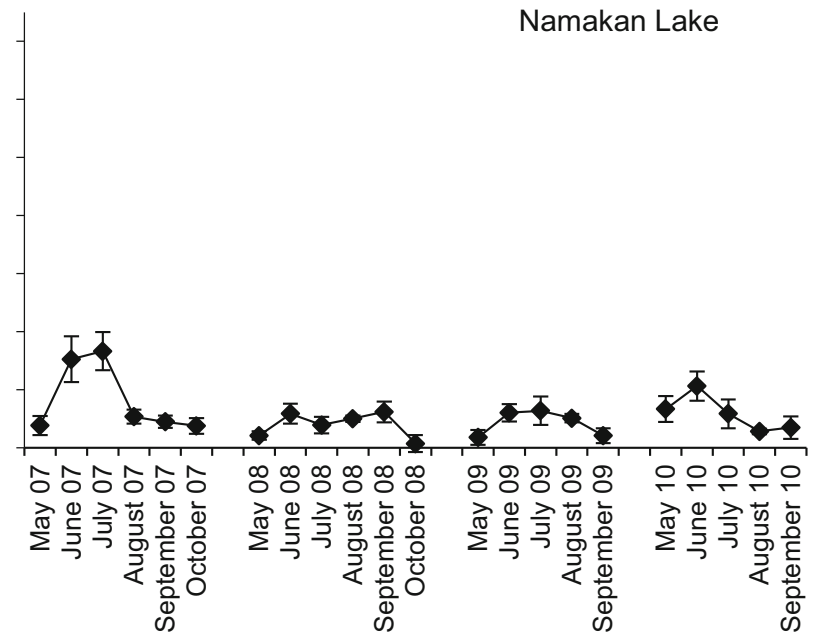


4 Fig. 8 Seasonal microcrustacean density patterns for three preBythotrephes (2001-2003) years are compared to four postBythotrephes years (2007-2010; mean monthly values \pm 1 SE). Examples are given for all three large lakes from the Temporal Contrast. Note that the density is much reduced in the postBythotrephes series and that the seasonal pattern reverses (low to high, pre-Bythotrephes; high to low, post-Bythotrephes)
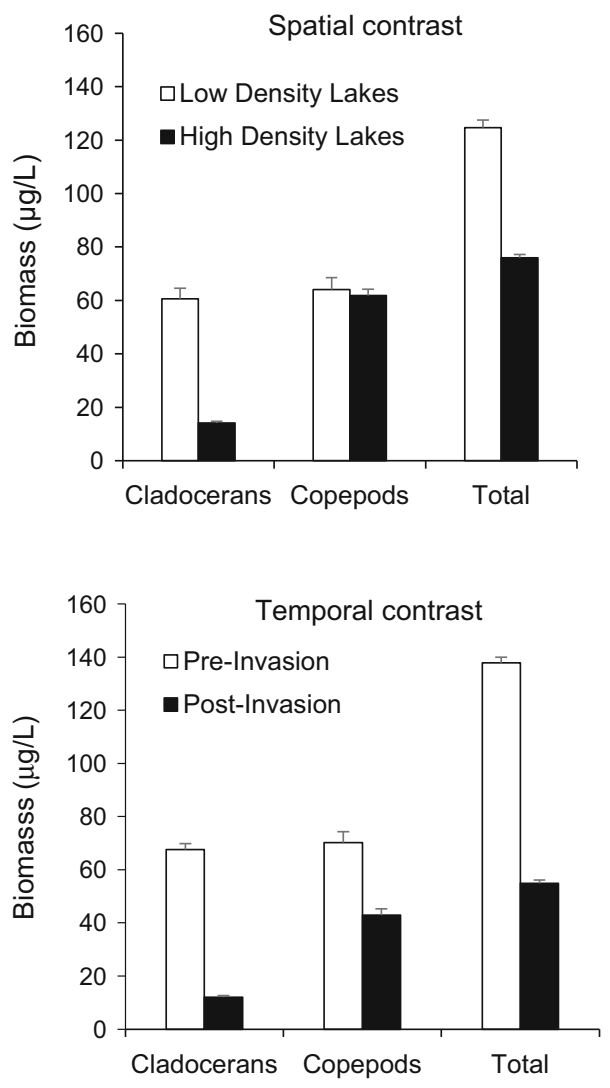

Fig. 9 Total biomass differences for Spatial and Temporal Contrasts. In the Spatial Contrast, biomass values for cladocerans, copepods, and total zooplankton are shown under lowBythotrephes (white) versus high-Bythotrephes (black) lakes. In the Temporal Contrast, biomass values are shown for beforeBythotrephes (white) and after-Bythotrephes (black) conditions (mean $\pm 1 \mathrm{SE}$ )

Decreases were sometimes less in the Spatial Contrast than in the Temporal Contrast comparisons, probably because Bythotrephes were present in all Spatial Contrast lakes, although at different relative densities, and there was the issue of water exchange between lakes. In comparison, the Temporal Contrast involved a simple $100 \%$ before-after comparison in the large lakes. The Spatial Contrast dichotomy ("low-density" versus "high density") involved clustering Crane Lake (0.3 Bythotrephes $\left./ \mathrm{m}^{3}\right)$ and Little Vermillion Lake $\left(0.5\right.$ individuals $\left./ \mathrm{m}^{3}\right)$ together with Sand Point Lake (5.7 individuals $/ \mathrm{m}^{3}$ ). The "highdensity" lakes featured similar, high densities (Rainy, Kabetogama, Namakan; 24-33 Bythotrephes $/ \mathrm{m}^{3}$ ). In addition, the large lakes were more closely connected relative to geographic distribution and water exchange, factors which probably contributed to similar high Bythotrephes densities. Some workers argue that Bythotrephes effects are evident at densities as low as 2-3 Bythotrephes $/ \mathrm{m}^{3}$ (Boudreau and Yan 2003). A separate cross-comparison between Sand Point Lake and the other two low-density lakes did show weak, but significant, effects $(45 \%$ reduction in cladoceran densities; ANOVA, $\mathrm{F}=5.84, p=0.018$, $\mathrm{F}$ crit $=3.99$ ). The weak effects, even at low densities, probably contribute to the reduced differences in the Spatial Contrast comparison relative to the Temporal Contrast result.

Whereas there was substantial (40-60\%) loss of summer standing zooplankton biomass in Voyageurs, there was an even greater reduction in secondary production (67\% decline) for three reasons: (1) serious reduction of summer-fall biomass, (2) loss of biomass during the warm season of the year (influencing $\mathrm{P} / \mathrm{B}$ ratio), and (3) a shift of the community towards calanoid copepods that have longer generation times (slower turnover) than cladoceran assemblages. Cladocerans are generally considered much more productive than copepods, about four times more productive (P/B ratios: cladocerans 0.16 , cyclopoid copepods 0.10; calanoid copepods 0.04; Shuter and Ing 1997). Cladocerans also have greater estimated filter-feeding rates for algae (Peters and Downing 1984), raising intriguing questions of cascading trophic effects up and down food webs. The decline in secondary production indicates a loss of energy available to higher trophic levels, one that may have cascading impacts on small planktivorous fish. Staples et al. (in prep) found growth rates of young-of-the-year yellow perch, for which Daphnia are a major dietary source during summer, to be reduced in both Rainy and Kabetogama lakes after the Bythotrephes invasion. Since yellow perch are an important prey item in these lakes, the observed decrease in growth rates could also affect piscivorous fish and birds as well.

The substantial decline in zooplankton biomass, and especially cladoceran filtration, in Voyageurs also 


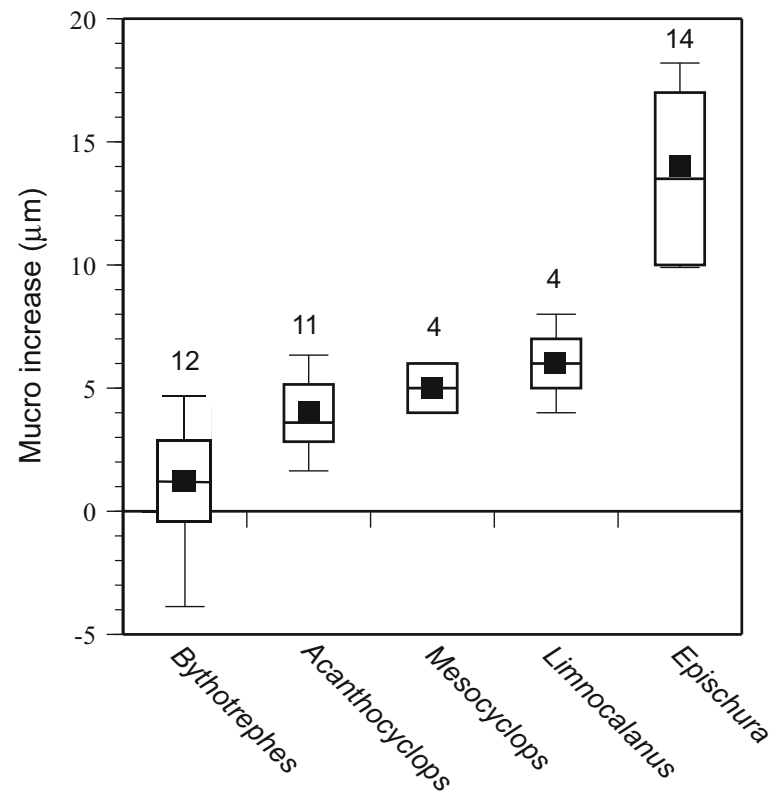

Fig. 10 Mean elongation of Bosmina spines (mucro, antennule) to Bythotrephes, Acanthocyclops, Mesocyclops, Limnocalanus, and Epischura in induction experiments. Number of experiments given above means and ranges. Mean length

sets up a test for grazing release of phytoplankton populations. Under conditions of abrupt grazer decline, we should expect an increase in phytoplankton biomass, especially under more productive (eutrophic, mesotrophic) conditions. If biomass perturbations are severe in lakes that differ in productivity, the top-down effects should allow for a convenient test of the "trophic cascade" hypothesis relative to bottom-up effects (Carpenter et al. 1985). In this regard, early comparisons of Bythotrephes invasion in oligotrophic Lake Michigan, did not associate cladoceran decrease with phytoplankton increase (Lehman 1988; Lehman and Cáceres 1993). A weak to nonexistent cascade effect was also reported by Strecker et al. (2011) for geographic comparison of 22 Canadian Shield lakes, following cladoceran depression by Bythotrephes. Productivity in those Canadian lakes was again very low, so that algae may be limited more by nutrient concentrations (bottom-up) than by grazing (top-down). Oligotrophic lakes are less likely to show top-down effects at lower trophic levels because of strong counter bottom-up forces (Leibold et al. 1997; Jeppesen et al. 2003). That is, grazers are more food-limited than predator-limited, so that release from predation does not result in a major

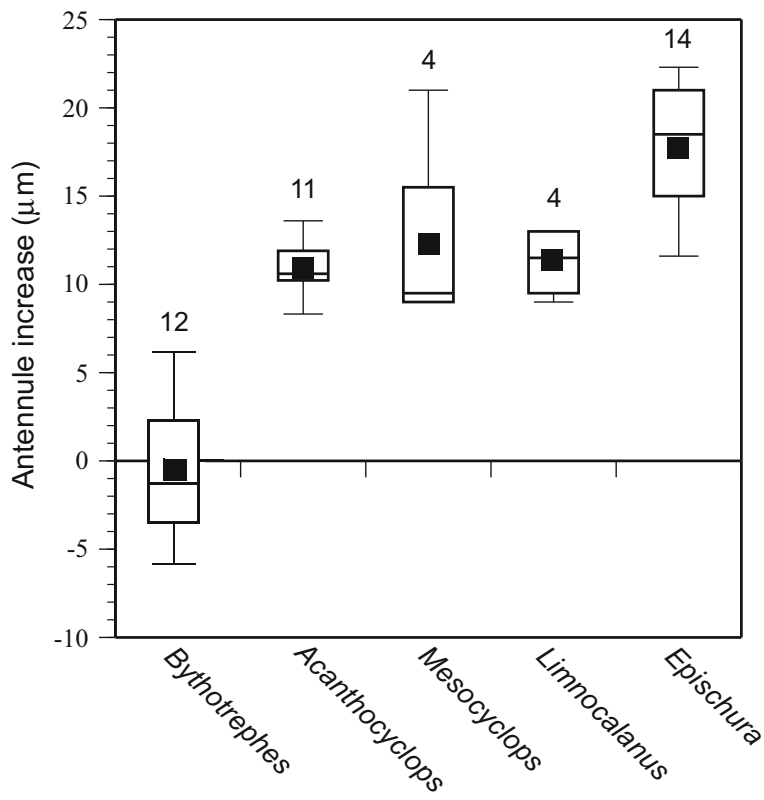

difference is recorded in microns (calculated as Predation length-Control length) and displayed as box and whisker diagrams [mean (black box), median (horizontal line), quartiles (horizontal box ends), and ranges (end whiskers)]

response. In experimental mesocosms, increases in chlorophyll (phytoplankton biomass) in the presence of Bythotrephes, consistent with trophic cascades, have been observed (Strecker and Arnott 2005). An intensive study of Kabetogama Lake, the most productive of the Voyageurs' lakes, conducted during 2008-2009, provided some evidence for increases in Chl $a$ concentrations and primary productivity compared to earlier measurements (Chrisensen et al. 2011), yet a direct connection to Bythotrephes presence has not yet been established.

In our studies, the primary mechanism of microcrustacean biomass depression seems to come through direct consumption of zooplankton species (Fig. 11). Spatial comparisons showed that most small cladoceran populations (D. retrocurva, Bosmina, Ceriodaphnia, Chydorus) were severely depressed in summer and early fall, when Bythotrephes was most abundant. Larger Daphnia mendotae showed only modest reductions, and persisted in the large lake complex. Daphnia mendotae has the ability to migrate into hypolimnetic waters, away from epilimnetic Bythotrephes, and this trait undoubtedly aids its survival in other large lakes (e.g. Lake Michigan; Lehman and Cáceres 1993; Pangle et al. 2007). 


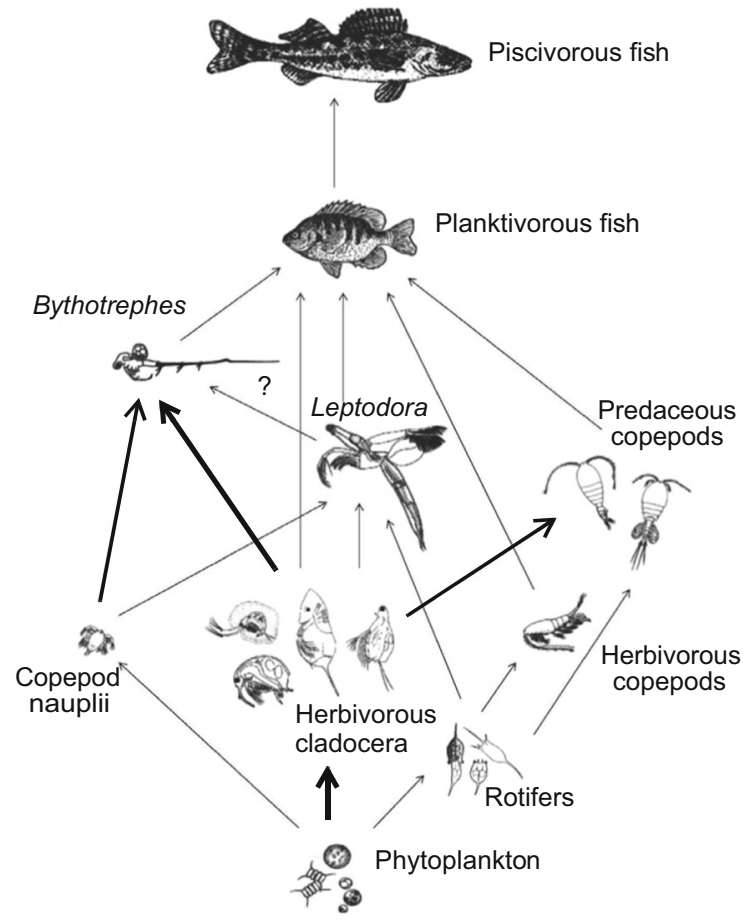

Fig. 11 Bythotrephes position in Voyaguers' food web. The spiny cladoceran is consumed by planktivorous fish, whereas it preys directly on cladocerans and copepod nauplii (direct interaction). Notice that omnivorous cyclopoids also draw from the small-bodied cladoceran pool, resulting in an "indirect interaction". Thickened arrows indicate relative impacts

Springtime abundances of cladocerans are strongly associated with Bythotrephes abundance (Young et al. 2011). However, the escape response of D. mendotae to Bythotrephes is also fairly effective (PichlovaPtacnikova and Vanderploeg 2011). It is intriguing that D. mendotae in the Laurentian Great Lakes contain D. galeata genes (Kerfoot and Weider 2004), which might account for some of the superior evasive traits (Bourdeau et al. 2013). Although not a smallbodied cladoceran, Daphnia pulicaria was severely reduced to one tenth of its former abundance. Severe reduction of $D$. pulicaria was also noted when Bythotrephes invaded Lake Michigan (Lehman and Cáceres 1993; Schulz and Yurista 1999). The large cladoceran Holopedium was exceptional in that it benefited from Bythotrephes presence in the Spatial Contrast data from Voyageurs, similar to the circumstance reported from Harp Lake (Yan and Pawson 1997; Yan et al. 2002). Holopedium is protected by virtue of being enclosed in a gelatinous sheath, which is recognized as an effective deterrent against invertebrate predators (Stenson 1973, 1987; O'Brien et al. 1979). Holopedium probably also benefited from reduced competition, as other cladocerans were driven to low densities.

Responses of individual copepod genera to Bythotrephes appeared more complex, probably operating through a combination of direct and indirect pathways (Fig. 11). In both the spatial and temporal comparisons, naupliar stages of copepods were reduced. Bythotrephes probably ingested cyclopoid nauplii as an important part of their diet, a circumstance noted by Nauwerck (1993), in Lake Huron enclosure experiments by Vanderploeg et al. (1993), and in Harp Lake enclosure studies by Dumitru et al. (2001). The latter should not be surprising, as naupliar stages appear to be vulnerable to Bythotrephes (Schulz and Yurista 1999), although copepodid and adult stages of calanoid and cyclopoid species possess better evasive swimming skills than cladocerans (Kerfoot et al. 1980; Schulz and Yurista 1999; Bowers and Vanderploeg 1982). Several omnivorous copepods suffered density declines. Mesocyclops was strongly depressed in both the spatial and temporal comparisons, whereas Diacyclops and Acanthocyclops were depressed marginally in the spatial comparison, and strongly in the temporal analysis. Adult cyclopoid copepods are rarely found in the diets of Bythotrephes (Lehman and Branstrator 1995; Schulz and Yurista 1999; Yurista et al. 2010). The major decreases of Mesocyclops, Diacyclops, and Acanthocyclops were probably indirect, a consequence of omnivorous copepodid to adult stages competing for prey items (small cladocerans and rotifers) depleted by Bythotrephes. Hence in our hypothesized food web (Fig. 11), we have Bythotrephes both directly and indirectly impacting cyclopoid copepods.

The observed responses in Voyageurs also resemble results from published mesocosm experiments. Strecker and Arnott (2005) found reductions in small cladocerans (Bosmina, Eubosmina), cyclopoid copepods and calanoid copepods, and again increases in Holopedium. Biomass and biodiversity repercussions were greatest in the initially most diverse community, counter to their initial expectations that high biodiversity in natural communities protects against consumer impacts from invasives.

We emphasize long-term concern about progressive, accumulative effects of Bythotrephes presence. In particular, prolonged contact with cladoceran prey 
in late summer and early fall leads to severe prey population declines during the prime period of diapause egg production, a condition that, if not reversed, will eventually lead to failure of spring egg hatching (recruitment). Although spring recruitment reduction appears evident in only a few species (Table 2; D. pulicaria; Bosmina; Chydorus), we suggest that egg bank depletion over time requires study and may contribute to long-term progressive negative effects.

In Europe, Bythotrephes often co-exists with the very array of species suppressed in North American Lakes. For example, in Lake Constance, Bythotrephes co-exists with two Daphnia species, two Bosmina species, Eudiaptomus gracilis, three cyclopoid copepod species, and the predatory cladoceran Leptodora kindtii (Straile and Haelbich 2000). Why does the spiny cladoceran, an invasive species, have such a widespread effect on North American resident assemblages, but not a comparable effect on European assemblages of similar composition? We would argue that natural selection and evolution of defensive mechanisms in prey species over time is a key response circumvented by Bythotrephes (for natural responses to Epischura and Leptodora, see Kerfoot and McNaught 2010). An upcoming article (Kerfoot and Savage 2016) discusses 55 split-clone experiments with three small prey species and 12 different predators from three locations in North America and three in Europe. The study shows that prey "countermeasures" are common in pelagic food-webs. We would argue that when a prey species fails to increase defenses to an efficient predator, something is seriously wrong. Although our example is admittedly only one taxon (Bosmina), we suggest that many New World zooplankton species are blind-sided, i.e. they simply do not recognize the presence of Bythotrephes in the water column and do not deploy natural behavioral (vertical migration) or morphological (body size, spines) defenses, the kinds of resistant traits that allow potentially vulnerable prey to co-exist with predators in natural assemblages.

Interpretations for Great Lakes communities

Because of multiple stressors, unraveling impacts of invasive species on Laurentian Great Lakes pelagic communities, the original source of Bythotrephes before its inland spread, poses problems. Factors such as other exotic species (quagga and zebra mussels), changes in fish stocking, or trends in nutrient loading (phosphate abatement), all complicate interpretations of top-down and bottom-up effects in the Laurentian Great Lakes (Bunnell et al. 2014). Another consideration is scale, for the enormous size and interconnected hydrodynamic nature of the Great Lakes creates conditions more suitable for metapopulation analysis. Yet there is a growing sense of urgency as planktonic biodiversity is related to lake size, and nowhere are there are there as many pelagic freshwater zooplankton species as in the Great Lakes (Dodson 1992; Kerfoot et al. 2001). The Voyageurs Lake system is also a large lake interconnected system, with relatively high species diversity, yet is not as complicated in time or space with ancillary issues (mussel introductions, fish or nutrient perturbations). Voyageurs could provide insight into how Bythotrephes perturbations now are influencing Laurentian Great Lakes zooplankton communities or will be influencing Lake Champlain. Recent collapse in alewife populations in the Great Lakes released Bythotrephes from top-down limitation (Jarnagin et al. 2004; Pothoven et al. 2007; Pothoven and Madenjian 2008), initiating increased Bythotrephes densities and a second round of microcrustacean community responses.

The responses to Bythotrephes' predation seem complex, but make sense as a simple top-down interaction. Bythotrephes' position in the lake's food web is illustrated in Fig. 11. The spiny cladoceran is consumed by planktivorous fish, and preys directly on cladocerans and copepod nauplii ("direct effect"). However, because omnivorous copepods also draw from the small-bodied cladoceran pool, there could also be an "indirect effect" upon cyclopoid densities.

After colonization in the mid-1980s, Bythotrephes rose to densities in Lake Michigan and Huron of 20-80 individuals $\mathrm{m}^{-3}$ by 1988-1998, then declined to 5-15 individuals $\mathrm{m}^{-3}$ in 1999. Initial impacts on zooplankton communities in Lakes Superior, Huron, and Michigan included declines in the following species: Leptodora kindtii, Daphnia pulicaria, Daphnia retrocurva, Eubosmina coregoni, and Mesocyclops edax, i.e., very similar to changes seen in Voyageurs. In the middle and eastern basins of Lake Erie, the list included two additional depressed taxa: Daphnia mendotae and Diaphanosoma birgei, again similar to changes observed in Voyageurs. Daphnia mendotae experienced an initial decline in Lakes Michigan and 
Huron (Lehman and Cáceres 1993), but subsequently increased to pre-Bythotrephes levels or above (Barbiero and Tuchman 2004). Again, there are similarities as D. mendotae seems to persist in Voyageurs. Since alewife collapse in Lake Ontario and subsequent Bythotrephes increase, Leptodora kindtii, Daphnia retrocurva, Bosmina and Eubosmina, Diaphanosoma birgei, and Mesocyclops edax have all seriously declined, whereas Holopedium gibberum has dramatically increased (Barbiero, personal communication), again very close to changes observed in Voyageurs.

Recent reductions of cyclopoid copepod species (Mesocyclops, Acanthocyclops, Diacyclops) in Lakes Michigan, Huron, and Ontario, also suggest the longterm trends seen in Voyageurs lakes. The cyclopoid collapses in the Laurentian Great Lakes were initially difficult to interpret (Kerfoot et al. 2010). However, the observed changes in the Laurentian Great Lakes so closely resemble modifications observed in Voyageurs assemblages following introduction of Bythotrephes, that they are interpretable as similar top-down direct and indirect effects, superimposed upon declining productivity (bottom-up effects) associated with quagga and zebra mussels. All these observations suggest that the microcrustacean declines recently observed in the Laurentian Great Lakes are not necessarily connected to the bottom-up declines in productivity brought about by mussels, but are more closely related to a secondary collapse of planktivorous fish density, one that has created a series of transitory perturbations coursing through the foodweb system in top-down fashion. At the moment, Laurentian Great Lakes assemblages also seem to be moving towards a set of calanoid copepods, Daphnia mendotae, and the resistant cladoceran Holopedium, again much as seen in Voyageurs National Park.

Acknowledgements The research reported here is part of a project assessing the presence and impact of Bythotrephes in parks of the Great Lakes region (e.g., Sleeping Bear Dunes National Lakeshore, Pictured Rocks National Lakeshore, Isle Royale National Park; Apostle Islands National Lakeshore, Grand Portage National Monument, Voyageurs National Park). Geographic survey sampling and Park studies during 2008-2010 were funded by a Grant from the National Park Service Natural Resource Preservation Program GLNF CESU Task Agreement No. J6067080012. Study of Lakes Superior and Michigan was aided by funds from NSF OCE-9726680 EEGLE CoOP (National Science Foundation and National Oceanic and Atmospheric and Atmospheric Administration Coastal Ocean Program, Episodic Events-Great Lakes Experiment) Grant to W.C.K.; NSF OCE-9712872 KITES CoOP (National Science
Foundation and National Oceanic and Atmospheric Administration Coastal Ocean Program, Keweenaw Interdisciplinary Transport Experiment In Superior) Grant to W.C.K.; and a NOAA Michigan Seagrant Award NA16RG1145, Project R/ER-19 to W.C.K. We thank Lora Loope, National Park Service, Pictured Rocks, for help in the distribution and sampling programs. Annie Putman aided Foad Yousef during the geographic field sampling. Jaime LeDuc and the other staff at Voyageurs National Park greatly aided field plankton sampling. Lucille Zelazny assisted on figure preparation. This is contribution number 30 of the Great Lakes Research Center at Michigan Tech.

Open Access This article is distributed under the terms of the Creative Commons Attribution 4.0 International License (http:// creativecommons.org/licenses/by/4.0/), which permits unrestricted use, distribution, and reproduction in any medium, provided you give appropriate credit to the original author(s) and the source, provide a link to the Creative Commons license, and indicate if changes were made.

\section{References}

Balcer MD, Korda NL, Dodson SI (1984) Zooplankton of the Great Lakes. University of Wisconsin Press, Madison

Barbiero RP, Tuchman ML (2004) Changes in the crustacean communities of Lakes Michigan, Huron and Erie following the invasion of the predatory cladoceran Bythotrephes longimanus. Can J Fish Aquat Sci 61(11):2111-2125. doi:10.1139/f04-149

Barnhisel DR (1991a) The caudal appendage of the cladoceran Bythotrephes cederstroemi as defense against young fish. J Plankton Res 13:529-537

Barnhisel DR (1991b) Zooplankton spine induces aversion in small fish predators. Oecologia 88:444-450. doi:10.1007/ BF00317591

Berg DJ, Garton DW (1988) Seasonal abundance of the exotic predatory cladoceran, Bythotrephes cederstroemi, in western Lake Erie. J Great Lakes Res 14(4):479-488

Boudreau SA, Yan ND (2003) The differ crustacean zooplankton communities of Canadian Shield lakes with and without the nonindigenous zooplanktivore Bythotrephes longimanus. Can J Fish Aquat Sci 60:1307-1313

Bourdeau PE, Pangle KL, Reed EM, Paacor SD (2013) Finely tuned response of native prey to an invasive predator in a freshwater system. Ecology 94:1449-1455. doi:10.1890/ 12-2116.1

Bowers JA, Vanderploeg HA (1982) In situ predatory behavior of Mysis relicta in Lake Michigan. Hydrobiologia 93:121-131

Branstrator DK, Lehman JT (1996) Evidence for predation by young-of-the-year alewife and bloater chub on Bythotrephes cederstroemi in Lake Michigan. J Great Lakes Res 22:917-924

Branstrator DK, Brown ME, Shannon LJ, Thabes M, Heimgartner K (2006) Range expansion of Bythotrephes longimanus in North America: evaluating habitat characteristics in the spread of an exotic zooplankter. Biol Invasions 8(6):1367-1379. doi:10.1007/s10530-005-5278-7 
Bunnell DB et al (2014) Changing ecosystem dynamics in the Laurentian Great Lakes: Bottom-up and top-down regulation. Bioscience 64:26-39. doi:10.1093/biosci/bit001

Carpenter SR, Kitchell JF, Hodgson JR (1985) Cascading trophic interactions and lake productivity. Bioscience 35:634-639

Chrisensen VG, Maki RP, Kiesling RL (2011) Relation of nutrient concentrations, nutrient loading, and algal production to changes in water levels in Kabetogama Lake, Voyageurs National Park, northern Minnesota, 2008-09. U.S. Geological Survey Scientific Investigations Report 2011-5096

Compton JA, Kerfoot WC (2004) Colonizing inland lakes: consequences of YOY fish ingesting the spiny cladoceran (Bythotrephes cederstroemi). J Great Lakes Res 30(supplement 1):315-326

Cox JG, Lima SL (2006) Naivete and an aquatic-terrestrial dichotomy in the effects of introduced predators. Trends Ecol Evol 21:674-680

Cullis K, Johnson G (1988) First evidence of the cladoceran Bythotrephes cederstroemii Shoedler in Lake Superior. Jour Great Lakes Res 14:524-525

Culver DA, Boucherle MM, Bean DJ, Fletcher JW (1985) Biomass of freshwater crustacean zooplankton from length-weight regressions. Can $\mathrm{J}$ Fish Aquat Sci 42:1380-1390. doi:10.1139/f85-173

Dodson S (1992) Predicting crustacean zooplankton richness. Limnol Oceanogr 37(4):848-856

Dumitru C, Sprules WG, Yan ND (2001) Impact of Bythotrephes longimanus on zooplankton assemblages of Harp Lake, Canada: an assessment based on predator consumption and prey production. Freshw Biol 46(2):241-251

Garton DW, Berg DJ, Fletcher RJ (1990) Thermal tolerance of the predatory cladocerans Bythotrephes cederstroemi and Leptodora kindtii relationship to seasonal abundance in Lake Erie. Can J Fish Aquat Sci 47:731-738

Haney JF et al (2013) An image-based key to the zooplankton of North America. University of New Hampshire Center for Freshwater Biology

Hargis JR, Wilson RM, Osgood RA, Weber TW, Adams LE (1981) Ecological analysis of the plankton communities of Voyageurs National Park. US Department of the Interior National Park Service, annual report June 16 1979-June 15 1980

Jarnagin ST, Swan BK, Kerfoot WC (2000) Fish as vectors in the dispersal of Bythotrephes cederstroemi: diapausing eggs survive passage through the gut. Freshw Biol 43:579-589

Jarnagin ST, Kerfoot WC, Swan BK (2004) Zooplankton life cycles: direct documentation of pelagic births and deaths relative to diapausing egg production. Limnol Oceanogr 49:1317-1332. doi:10.4319/lo.2004.49.4_part_2.1317

Jeppesen E et al (2003) The impact of nutrient state and lake depth on top-down control in the pelagic zone of lakes: a study of 466 lakes from the temperate zone to the Arctic. Ecosystems 6:313-325. doi:10.1007/s10021-002-0145-1

Kallemeyn LW, Holmberg KL, Perry JA, Odde BY (2003) Aquatic synthesis for Voyageurs National Park. US Geological Survey, information and technology report 2003-0001

Kelly NE, Yan ND, Walseng B, Hessen DO (2013) Differential short- and long-term effects of an invertebrate predator on zooplankton communities in invaded and native lakes. Divers Distrib 19:396-410

Kerfoot WC (1987) Translocation experiments: Bosmina responses to copepod predation. Ecology 68:596-610

Kerfoot WC (1988) Defensive spines: inverse relationship between coefficients of variation and size. Limnol Oceanogr 33(6, part 1):1412-1429

Kerfoot WC (2006) Baltic Eubosmina morphological radiation: sensitivity to invertebrate predators (induction) and observations on genetic differences. Arch Hydrobiol 167:147-168

Kerfoot WC, McNaught AS (2010) Two-step dialogue between the cladoceran Bosmina and invertebrate predators: induction and natural selection. Limnol Oceanogr 55(1):403-419

Kerfoot WC, Savage SC (2016) Multiple inducers in aquatic foodwebs: Counter-measures and vulnerability to exotics. Limnol Oceanogr 61:382-406

Kerfoot WC, Weider LJ (2004) Experimental paleoecology (resurrection ecology): chasing Van Valen's Red Queen Hypothesis. Limnol Oceanogr 49:1300-1316

Kerfoot WC, Kellogg DL, Strickler JR (1980) Visual observations of live zooplankters: Evasion, escape, and chemical defenses. In: Kerfoot WC (ed) Evolution and ecology of zooplankton communities. University Press of New England, Hanover, pp 10-27

Kerfoot WC, McNaught AS, Jarnagin ST (2001) Invertebrate predators and fish: biogeographic patterns and fish dispersal of resting eggs. Verh Internat Verein Limnol 27:1841-1850

Kerfoot WC, Yousef F, Green SA, Budd JW, Schwab DJ, Vanderploeg HA (2010) Approaching storm: disappearing winter bloom in Lake Michigan. J Great Lakes Res 36:30-41

Kerfoot WC, Yousef F, Hobmeier MM, Jarnigan ST, Churchill JH (2011) Temperature relationships and recreational fishing: Inland dispersal of spiny waterfleas (Bythotrephes longimanus). Biol Invasions 13:2513-2531

Korovchinsky NM (2000) Species richness of pelagic Cladocera of large lakes in the eastern hemisphere. Hydrobiologia 434:41-54

Lehman JT (1987) Palearctic predator invades North American Great Lakes. Oecologia 74:478-480

Lehman JT (1988) Algal biomass unaltered by food-web changes in Lake Michigan. Nature 332:537-538

Lehman JT (1991) Causes and consequences of the cladoceran dynamics in Lake Michigan. Implications of the species invasion by Bythotrephes. J Great Lakes Res 17:437-445. doi:10.1016/S0380-1330(91)71379-8

Lehman JT, Branstrator DK (1995) A model for growth, development, and diet selection by the invertebrate predator Bythotrephes cederstroemi. J Great Lakes Res 21:610-619. doi:10.1016/S0380-1330(95)71072-3

Lehman JT, Cáceres CE (1993) Food-web responses to species invasion by a predatory invertebrate: Bythotrephes in Lake Michigan. Limnol Oceanogr 38:879-891. doi:10.4319/lo. 1993.38.4.0879

Leibold MA, Chase JM, Shurin JB, Downing AL (1997) Species turnover and the regulation of trophic structure. Ann Rev Ecol Syst 28:467-494. doi:10.1146/annurev.ecolsys.28.1.467

MacIsaac HJ, Ketelaars HAM, Grigorovich IA, Ramcharan C, Yan ND (2000) Modeling Bythotrephes longimanus invasions in the Great Lakes basin based on its European distribution. Archiv Hydrobiol 149:1-21 
MacIsaac HJ, Borbely JVM, Muirhead J, Graniero PA (2004) Backcasting and forecasting biological invasions of inland lakes. Ecol Appl 14(3):773-783. doi:10.1890/02-5377

Manca M, Comoli P (2000) Biomass estimates of freshwater zooplankton from length-carbon regression equations. J Limnol 59:15-18

McNaught AS, Kiesling RL, Ghadouani A (2004) Changes to zooplankton community structure following colonization of a small lake by Leptodora kindtii. Limnol Oceanogr 49:1239-1249

Mills EL, Gorman RO, DeGisi J, Herberger RF, House RA (1992) Food of the alewife (Alosa pseudoharengus) in Lake Ontario before and after the establishment of Bythotrephes cederostroemi. Can J Fish Aquat Sci 49:2009-2019

Mills EL, Leach JH, Carlton JT, Secor CL (1993) Exotic species in the Great Lakes: a history of biotic crises and anthropogenic introductions. J Great Lakes Res 19:1-54

Nauwerck A (1993) Migration strategies of crustacean zooplankton in Lake Mondsee. Arch Hydrobiol 39:123-136

O'Brien WJ, Kettle D, Riessen H (1979) Helmets and invisible armor: structures reducing predation from tactile and visual planktivores. Ecology 60(2):287-294

Pangle KL, Peacor SD, Johannsson OE (2007) Large nonlethal effects of an invasive invertebrate predator on zooplankton population growth rate. Ecology 88(2):402-412. doi:10. 1890/06-0768

Peters RH, Downing JA (1984) Empirical analysis of zooplankton filtering and feeding rates. Limnol Oceanogr 29(4):763-784

Pichlova-Ptacnikova R, Vanderploeg HA (2011) The quick and the dead: might differences in escape rates explain the changes in the zooplankton community composition of Lake Michigan after invasion by Bythotrephes? Biol Invasions 13:2595-2604

Pothoven SA, Madenjian CP (2008) Alewife and lake whitefish: changes in consumption following dreissenid invasions in Lakes Michigan and Huron. J Fish Manag 28:308-320

Pothoven SA, Vanderploeg HA, Cavaletto JF, Krueger DM, Mason DM, Brandt SB (2007) Alewife planktivory controls the abundance of two invasive predatory cladocerans in Lake Michigan. Freshwat Biol 52:561-573

Ricciardi A (2006) Patterns of invasion in the Laurentian Great Lakes in relation to changes in vector activity. Divers Distrib 12:425-433. doi:10.1111/j.1366-9516.2006.00262.x

Sala OE, Chapin FS III et al (2000) Biodiversity- global biodiversity scenarios for the year 2100. Science 287:1770-1774

Schulz KL, Yurista PM (1999) Implications of an invertebrate predator's (Bythotrephes cederstroemi) atypical effects on a pelagic zooplankton community. Hydrobiologia 380:179-193. doi:10.1023/A:1003484813672

Shave CR, Townsend CR, Crowl TA (1994) Antipredator behaviors of a freshwater crayfish (Paranephrops zealandicus) to a native and an introduced predator. New Zealand J Ecol. 18:1-10

Shuter BJ, Ing KK (1997) Factors affecting the production of zooplankton in lakes. Can J Fish Aquat Sci 54:359-377

Simberloff D, Van Holle B (1999) Positive interactions of nonindigenous species: invasional meltdown? Biol Invasions 1(1):21-32

Smith GR, Boyd A, Dayer CB, Winter KE (2008) Behavioral responses of American toad and bullfrog tadpoles to the presence of cues from the invasive fish, Gambusia affinis. Biol Invasions 10:743-748

Stenson J (1973) On predation and Holopedium gibberum (Zaddach) distribution. Limnol Oceanogr 18:1005-1010

Stenson J (1987) Variation in capsule size of Holopedium gibberum (Zaddach): a response to invertebrate predation. Ecology 68(4):928-934

Straile D, Haelbich A (2000) Life history and multiple antipredator defenses of an invertebrate pelagic predator, Bythotrephes longimanus. Ecology 81(1):150-163

Strecker AL, Arnott SE (2005) Impact of Bythotrephes invasion on zooplankton communities in acid-damaged and recovered lakes on the Boreal Shield. Can J Fish Aquat Sci 62:2450-2462. doi:10.10.1139/f05-152

Strecker AL, Beisner BE, Arnott SE, Paterson AM, Winter JG, Johannsson OE, Yan ND (2011) Direct and indirect effects of an invasive planktonic predator on pelagic food webs. Limnol Oceanogr 56(1):179-192

Taylor DJ, Ishiane CR, Haney RA (2002) The systematics of Holarctic bosminids and a revision that reconciles molecular and morphological evolution. Limnol Oceanogr 47:1486-1495

Vanderploeg HA, Liebig JR, Omair M (1993) Bythotrephes predation on Great Lakes' zooplankton measured by an in situ method: implications for community structure. Arch Hydrobiol 127:1-8

Vitousek PM, D'Antonio CM, Loope LL, Westbrooks R (1996) Biological invasions as global environmental change. Am Sci 84:468-477

Wahlstrom E, Westman E (1999) Planktivory by the predacious cladoceran Bythotrephes longimanus: effects on zooplankton size structure and abundance. Can J Fish Aquat Sci 56:1865-1872

Wilkinson L (2007) SYSTAT: The system for statistics. SYSTAT, Inc.

Yan ND, Pawson TW (1997) Changes in the crustacean zooplankton community of Harp Lake, Canada following the Bythotrephes cederstroemi invasion. Freshwat Biol 37:409-425. doi:10.1046/j.1365-2427.2008.01954.x

Yan ND, Blukacz A, Sprules WG, Kindy PK, Hackett D, Girard RE, Clark BJ (2001) Changes in zooplankton and the phenology of the spiny water flea, Bythotrephes, following its invasion of Harp Lake, Ontario, Canada. Can J Fish Aquat Sci 58:2341-2350. doi:10.1139/f01-171

Yan ND, Girard R, Boudreau S (2002) An introduced invertebrate predator (Bythotrephes) reduces zooplankton species richness. Ecol Lett 5:481-485

Young JD, Strecker AL, Yan ND (2011) Increased abundance of the non-indigenous zooplanktivore, Bythotrephes longimanus, is strongly correlated with greater spring prey availability in Canadian Shield lakes. Biol Invasions 13:2605-2619. doi:10.1007/s10530-011-0077-9

Yurista PM (1999) A model for temperature correction of sizespecific respiration in Bythotrephes cederstroemi and Daphnia middendorffiana. J Plankton Res 21(4):721-734

Yurista PM, Vanderploeg HA, Liebig J, Cavaletto JF (2010) Lake Michigan Bythotrephes prey consumption estimates for 1994-2003 using a temperature and size corrected bioenergetic model. J Great Lakes Res 36(sp3):74-82. doi:10.1016/j.jglr.2010.03.007 